\title{
Serum biomarkers for the detection of cardiac toxicity after chemotherapy and radiation therapy in breast cancer patients
}

\section{Sibo Tian ${ }^{1}$, Kim M. Hirshfield ${ }^{2}$, Salma K. Jabbour ${ }^{1}$, Deborah Toppmeyer ${ }^{2}$, Bruce G. Haffty ${ }^{1}$, Atif J. Khan ${ }^{1}$ and Sharad Goyal ${ }^{1 *}$}

1 Department of Radiation Oncology, Rutgers Cancer Institute of New Jersey and Rutgers Robert Wood Johnson Medical School, New Brunswick, NJ, USA

2 Division of Medical Oncology, Rutgers Cancer Institute of New Jersey and Rutgers Robert Wood Johnson Medical School, New Brunswick, NJ, USA

Edited by:

John Varlotto, University of

Massachusetts Medical Center, USA

Reviewed by:

Dalong Pang, Georgetown University Hospital, USA

Michael Wayne Epperly, University of Pittsburgh Cancer Institute, USA

*Correspondence.

Sharad Goyal, Department of

Radiation Oncology, Rutgers Cancer Institute of New Jersey, 195 Little

Albany Street, New Brunswick, NJ 08903, USA

e-mail:goyalsh@rutgers.edu
Multi-modality cancer treatments that include chemotherapy, radiation therapy, and targeted agents are highly effective therapies. Their use, especially in combination, is limited by the risk of significant cardiac toxicity. The current paradigm for minimizing cardiac morbidity, based on serial cardiac function monitoring, is suboptimal. An alternative approach based on biomarker testing, has emerged as a promising adjunct and a potential substitute to routine echocardiography. Biomarkers, most prominently cardiac troponins and natriuretic peptides, have been evaluated for their ability to describe the risk of potential cardiac dysfunction in clinically asymptomatic patients. Early rises in cardiac troponin concentrations have consistently predicted the risk and severity of significant cardiac events in patients treated with anthracycline-based chemotherapy. Biomarkers represent a novel, efficient, and robust clinical decision tool for the management of cancer therapy-induced cardiotoxicity. This article aims to review the clinical evidence that supports the use of established biomarkers such as cardiac troponins and natriuretic peptides, as well as emerging data on proposed biomarkers.

Keywords: breast cancer, cardiac biomarkers, chemotherapy, radiation therapy, cardiotoxicity

\section{INTRODUCTION}

Due to earlier detection and highly effective multi-modality treatments, cancer has become a largely curable disease and a chronic illness. There were an estimated 11.7 million cancer survivors in 2007, a number that has grown from 3.0 million in 1970, to 9.8 million in 2001 (1). The Centers for Disease Control estimated in 2007 that $64.8 \%$ of cancer survivors had lived at least 5 years past their initial diagnosis, and approximately $60 \%$ of survivors were at least 65 years old. Because of the now-chronic nature of malignant diseases, and the age composition of the survivors, the cardiac side effects of cancer treatments must be heeded. Cytotoxic chemotherapies such as doxorubicin, targeted therapies including trastuzumab, and radiotherapy have all been implicated as risk factors for subsequent cardiac disease. The timing of cardiac toxicity can vary from acutely during treatment, to chronically months after treatment completion. The most clinically significant endpoint is impaired left ventricular ejection fraction (LVEF) and ensuing symptomatic heart failure. The current standard of detection is by serial echocardiography, a resource-intensive test whose accuracy is operator-dependent. Biomarkers on the other hand, can be tested at closer intervals given its low-cost approach; and its accuracy is independent of operator skill. Most importantly, biomarkers have demonstrated the ability to predict cardiotoxicity before it becomes clinically apparent. The use of cardiac biomarker in specific settings have been reviewed several times, and most recently in 2011 (2-6). However, the role of biomarkers is continually redefined by ongoing investigations. The purpose of this review is to provide a comprehensive assessment of the evidence on cardiac troponins and natriuretic peptides as biomarkers of cardiac toxicity. Results for other proposed biomarkers, including heart-type fatty acid-binding protein (H-FABP), glycogen phosphorylase isoenzyme $\mathrm{BB}$ (GPBB), C-reactive protein (CRP), myeloperoxidase (MPO), and nitric oxide (NO) will also be examined.

\section{CARDIAC TOXICITY AFTER CANCER TREATMENT}

Anthracyclines (AC), either used alone, or in combination with other chemotherapy agents, are widely used agents for the treatment of breast cancer (7). However, their use has been limited by significant cardiotoxicity (8). AC-induced injury has been described as "type I" cardiotoxicity, a dose-dependent, progressive, and generally irreversible type of toxicity (9). Its mechanism is based on oxidative damage, mediated by reactive oxygen species, and leads to necrosis and apoptosis (10). Risk of developing AC-induced cardiotoxicity varies between individuals, and even low doses have led to clinical cardiac dysfunction for certain patient subsets (11). Risk factors for developing AC-induced cardiotoxicity include cumulative dose, age, female gender, exposure to cardiotoxic agents, prior AC chemotherapy, and mediastinal radiation. The clinical manifestations of AC-associated cardiotoxicity range from left ventricular dysfunction to progressive cardiomyopathy. Doxorubicin administration is generally limited to a cumulative dose of $600 \mathrm{mg} / \mathrm{m}^{2}$ in patients without underlying cardiac morbidity (12). 
The pediatric population is particularly susceptible to ACinduced cardiomyopathy; and there is likely no safe dose in children (13). The incidence of cardiotoxicity after AC treatment in childhood is similarly dose-dependent: $11,23,47$, and $100 \%$ suffered from cardiac complications after being treated with $<400$, 400-599, 600-799, and $>800 \mathrm{mg} / \mathrm{m}^{2}$ of AC-based chemotherapy $(14,15)$. Treatment with ACs has long-term implications. Survivors of pediatric cancers are 8.2 times more likely to die from cardiac causes than the general population, and 15 times more likely to experience heart failure, with some eventually requiring heart transplants (16-18).

About $25-30 \%$ of breast cancers overexpress the cell surface receptor HER2. These malignancies are typically more aggressive, with enhanced proliferation and metastatic potential, and are associated with poor prognosis (19). Trastuzumab (Herceptin) is a monoclonal antibody that binds to the extracellular domain of the HER2 protein. Its efficacy in the adjuvant setting has been investigated in numerous clinical trials. A meta-analysis demonstrated reduction in mortality, recurrence and metastases rates, and improved disease-free survival with trastuzumab (20). Trastuzumab, though generally well tolerated, is associated with an infrequent but clinically significant risk of long-term cardiotoxicity. Unlike AC-induced cardiac injury, trastuzumab is described as "type II" cardiotoxicity. The risk of damage is doseindependent, generally reversible with discontinuation, and causes minimal ultrastructural changes (21-23). The risk of developing trastuzumab-induced heart failure has been reported as 2$4 \%$ when given alone, but as high as $27 \%$ when administered in conjunction with ACs $(24,25)$. With the advent of newer HER2-directed therapies, additional consideration will need to be given to long-term cardiac side effects associated with their use. Clinical trials have reported fewer grade three or four cardiac toxicity with lapatinib, pertuzumab, trastuzumab emtansine (T-DM1), or neratinib in comparison to trastuzumab (26-34). As other HER2-targeted agents are under development or evaluation for combinatorial therapy, cardiotoxicity will remain a topic of interest.

Radiation therapy (RT) is major component cancer treatment; and adjuvant radiotherapy for breast cancer reduces the risk of local recurrences and mortality (35). However, mediastinal irradiation has been linked to increased cardiotoxicity, via micro- and macrovascular damage $(36,37)$. A surveillance, epidemiology, and end results (SEER) analysis of 15,165 breast cancer patients found that of those who died more than 10 years after radiotherapy, $42 \%$ died from recurrent breast cancer, while $22 \%$ died from heart disease (38). The severity of cardiac injury is related to the radiation dose absorbed by the heart, and mean heart dose is typically higher when RT is to employed to treat left-sided breast cancer. The SEER study found patients with left-sided cancers had a $44 \%$ increased risk of cardiac mortality. Based on several randomized studies, the relative risk for significant cardiac events ranges 1.2-3.5 after RT (39). As RT is often combined with chemotherapy, cardiac irradiation has been described repeatedly as an additional risk factor for AC-induced cardiotoxicity $(40,41)$. Though data are still maturing on the cardiac risks of radiotherapy delivered concurrently with trastuzumab, an analysis of the NCCTG N9831 trial showed no additional cardiotoxicity with RT (42). Advances in radiation delivery technology, such as conformal radiation, which limit the amount of radiation absorbed by the myocardium, have proven useful in reducing the burden of radiation-induced cardiac morbidity $(38,43,44)$. Regardless, prior mediastinal irradiation remains a significant cause of excessive mortality.

\section{DETECTION OF CARDIAC DYSFUNCTION}

Clinically detectable cardiotoxicity is generally preceded by an interval of subclinical cardiac dysfunction. The ability to assess the risk of potential cardiac impairment has three major implications. Risk stratification provides an opportunity to modify ongoing treatment, alter the frequency of subsequent surveillance, and to provide direct interventions to reduce the risk of cardiotoxicity. For these reasons, techniques for early and reliable detection of clinically silent cardiotoxicity have been widely studied. Though several methods been explored, the optimal approach and timing of monitoring cardiac function remains an area of active investigation.

Serial endomyocardial biopsies, though considered the gold standard are invasive and impractical for routine screening purposes (45). The most prevalent screening method is based on measuring LVEF before, during, and after chemotherapy with conventional 2-D transthoracic echocardiography (TTE) (46). Monitoring with multiple-gated acquisition (MUGA) radionuclide angiography has also been recommended on the basis of improved accuracy (47). Because 2-D TTEs can be often limited by operator skill, and inherently less reproducible, efforts have been directed toward increasing its precision with refinements such as 3-D echocardiography, strain and strain rate measurements, and cardiac magnetic resonance (48-51). LVEF measurements based on cardiac imaging lack the sensitivity to detect early subclinical cardiotoxicity, and as a corollary, the ability to predict future declines in cardiac function $(52,53)$. Detectable changes in LVEF usually coexist with significant functional impairment, at which point the ability to regain normal cardiac function becomes limited. Thus, the traditional approach for detecting subclinical signs of cardiotoxicity is suboptimal and there remains a need to effectively identifying patients who are at risk of developing serious cardiac complications after chemotherapy or RT.

Over the past 15 years, serum molecules, such as cardiac troponins and natriuretic peptides, have been evaluated for their role as biomarkers of cardiac toxicity in the oncology setting. The ability of these biomarkers to identify patients with potential cardiac morbidity has been investigated in adult and pediatric populations, after chemotherapy, radiation, and targeted therapies. Biomarkers represent a non-invasive, resource-efficient, and robust approach to risk-stratify patients who have undergone cardiotoxic treatments.

\section{CARDIAC TROPONINS}

Cardiac troponin I ( $\mathrm{TnI})$ and cardiac troponin $\mathrm{T}(\mathrm{TnT})$ are two highly sensitive and specific biomarkers of cardiac damage. They are two tissue-specific isoforms of proteins that constitute the contractile apparatus in cardiac muscle. Since 2000, the European Society of Cardiology and the American Cardiac College of Cardiology have recognized cardiac troponins for their role in the diagnosis of acute myocardial infarctions $(54,55)$. Cardiac 
troponins have been useful in quantifying the extent of acute cardiomyocyte injury in many other clinic settings, including heart failure, pulmonary embolism, stroke, sepsis, and drug-induced cardiotoxicity (56-58). Notably, because cardiac troponin concentrations have been linked to the severity of myocyte injury and subsequent clinical outcomes, troponins have become a tool for risk stratification.

The validity of using cardiac troponins in detecting chemotherapy-induced cardiotoxicity was demonstrated in an early animal study that linked TnT elevations to histologic evidence of cardiac damage (59). Using spontaneously hypertensive rats treated with increased higher doses of doxorubicin, TnT and Billingham cardiomyopathy scores (based on number of myocytes showing myofibrillar loss and cytoplasmic vacuolization) were both related to the cumulative dose of doxorubicin. Cardiac troponins have consistently demonstrated clinical value in predicting subsequent cardiotoxicity after high-dose chemotherapy (HDC), irrespective of cancer type. This result is based on four major experiences that enrolled approximately 200-700 patients each (Table 1) (60-63). Cardiac troponins are sensitive and specific markers in predicting the development, and severity of, subsequent ventricular dysfunction. The largest study, involving 703 patients (46\% breast cancer) with advanced cancers treated with HDC (62). TnI was assayed immediately and 1 month after chemotherapy, while cardiac function was measured by LVEF at baseline, and 1, 2, 6, and 12 months after completing chemotherapy. Thirty percent (208) of patients demonstrated immediate TnI elevations, and 30\% of that subset showed elevated $\mathrm{TnI}$ on repeat testing at 1 month. Maximal LVEF reduction was predicted by both persistent $(r=0.92, p<0.001)$, and early $(r=0.78, p<0.001)$ troponin elevations. Most importantly, TnI proved to be a biomarker with clinical implications, and not simply a proxy for imaging-based measures. Forty-four percent of patients with persistent $\mathrm{TnI}$ elevations developed symptomatic heart failure, compared to $12 \%$ in the early positive group, and $0.2 \%$ in the TnI negative population. Troponin positivity over $0.08 \mathrm{ng} / \mathrm{m}^{2}$ predicted future cardiac events with a positive predictive value (PPV) of $84 \%$ and negative predictive value (NPV) of $99 \%$. TnI's high NPV has been a recurrent theme seen in many studies.

Left ventricular ejection fraction compromises with high-dose chemo can be evident as early as the first month, and was typically followed by progressive deterioration over the next year (61). In addition, smaller studies have found substantial relationships between troponin velocity during early follow-up and decreased LVEF (83). Elevated troponins have been implicated in predicting diastolic dysfunction via parameters such as E/A ratio in particular patient subsets treated with AC (69). Conversely, the role for troponin in low and moderate chemotherapy doses in unclear, as evaluated in a study with 100 patients treated with AC (median cumulative dose $226.1 \mathrm{mg} / \mathrm{m}^{2}$ ) (71). Even with TnT being assayed at five intervals from the first dose of chemotherapy to 12 months after its completion, no patient had recorded TnT values above the $0.1-\mathrm{ng} / \mathrm{ml}$ threshold. Of those who showed TnT rises after treatment, the majority reported normal LVEF and E/A ratio values just 1 year after completing chemotherapy.
Notably, cardiac troponins have been key in facilitating the evaluation of cardioprotective agents in two prospective randomized trials $(68,84)$. Both randomized children diagnosed with acute lymphoblastic leukemia (ALL) to doxorubicin with or without dexrazoxane, a free radical scavenger. In both studies, dexrazoxane drastically reduced the incidence of above-threshold values TnT during treatment. In the more recent experience, TnI levels during the first 90 days of treatment predicted lower LV mass and LV end-diastolic posterior wall thickness 4 years later (84).

Reports of troponin as a prognostic tool in asymptomatic survivors of childhood cancers have been largely disappointing. An early study of children treated with doxorubicin found the magnitude of TnT elevation after the first dose of chemotherapy predicted for the risk of subsequent echocardiographic abnormalities, including LV dilation $(r=0.8, p=0.003)$, and LV wall thinning ( $r=0.61, p=0.04) 9$ months later (65). The timing of injury markers supported the hypothesis that AC-induced injury can begin as early as the first dose, and is driven by continuous oxidative stress rather than acute necrosis. However, numerous studies discovered either no above-threshold troponin values, or lacked substantial relation with late-onset cardiac toxicity in survivors of childhood malignancies $(67,74,87,90)$.

In parallel with the growing usage of adjuvant trastuzumab in patients with HER2 overexpressing or amplified breast cancer, several large-scale studies have found a well-defined relationship between either troponin value or its interval change and tratuzumab-induced cardiac dysfunction. Cardinale et al. provided the earliest evidence cardiac troponin values can stratify patients on risk of developing trastuzumab-induced cardiotoxicity, based on 251 breast cancer patients who were followed for a median of 14 months after completion of trastuzumab treatment (75). Thereafter, systolic function (LVEF) was evaluated via echocardiography at baseline, every 3 months during trastuzumab treatment and the first year of follow-up, and then every 6 months. Forty-two (17\%) patients developed cardiac review and evaluation committee (CREC)-defined cardiac dysfunction; however, those with above-threshold TnI concentrations were at significantly higher risk for cardiotoxicity ( 62 vs. $5 \%, p<0.001$ ). Moreover, TnI positivity was the strongest independent predictor of cardiotoxicity $(\mathrm{HR}=17.6, p<0.001)$ and persistent LVEF impairment (HR $2.33, p<0.001)$. Troponin positivity predicted LVEF recovery with a PPV of $65 \%$ and NPV of $100 \%$. This suggested that negative TnI measurements during treatment can be used to assign a lower risk status to select patients who are less likely to benefit from cardiac screening at routine intervals.

With regard to the timing of troponin rises with trastuzumab treatment, Morris et al. found peak TnI elevations peaked occurred approximately 2 months and four after dose-dense AC-based chemotherapy (79). Importantly, it preceded maximum LVEF decline by 4 months. Two studies by Sawaya et al. supported these results. Both examined TnI in patients who were treated with AC and trastuzumab sequentially. They first found that elevated highsensitivity (hs)TnT measurements 3 months after chemotherapy was an independent predictor of cardiac toxicity at 6 months (81). The follow-up study combined circulating biomarkers with echocardiographic measures to refine their predictive model. Using an ultrasensitive troponin assay that established $30 \mathrm{pg} / \mathrm{ml}$ 
Table 1 | Role of cardiac troponins in the evaluation of chemotherapy and radiation-induced cardiotoxicity.

\begin{tabular}{|c|c|c|c|c|c|c|c|}
\hline Reference & Population & $\mathbf{N}$ & Treatment & Tn type & Cutoff & Troponin evaluations & Results and conclusions \\
\hline $\begin{array}{l}\text { Lipshultz et al. } \\
\text { (65) }\end{array}$ & ALL & 15 & ACs & $\mathrm{T}$ & $0.03 \mathrm{ng} / \mathrm{ml}$ & $\begin{array}{l}\text { Baseline, and } 1-3 \text { days after } \\
\text { each cycle }\end{array}$ & $\begin{array}{l}\text { Correlation between TnT and } \\
\text { LV end-diastolic dimension } \\
\text { and wall thickness }\end{array}$ \\
\hline $\begin{array}{l}\text { Herman et al. } \\
\text { (59) }\end{array}$ & Animal study & 37 & ACs & $\mathrm{T}$ & & $\begin{array}{l}\text { Before, and } 1 \text { week after } \\
\text { chemotherapy }\end{array}$ & $\begin{array}{l}\text { TnT and histological } \\
\text { myocardial changes in both } \\
\text { related to cumulative } \\
\text { doxorubicin dose }\end{array}$ \\
\hline $\begin{array}{l}\text { Cardinale et al. } \\
(60)\end{array}$ & Various & 204 & $\mathrm{HDC}$ & । & $0.5 \mathrm{ng} / \mathrm{ml}$ & $\begin{array}{l}\text { Before, and } 0,12,24,36, \text { and } \\
72 \mathrm{~h} \text { after every cycle }\end{array}$ & $\begin{array}{l}\text { Elevated TnI during treatment } \\
\text { predicted for LVEF decline }\end{array}$ \\
\hline $\begin{array}{l}\text { Auner et al. } \\
\text { (66) }\end{array}$ & $\begin{array}{l}\text { Hematologic } \\
\text { malignancies }\end{array}$ & 78 & ACs & $\mathrm{T}$ & $0.03 \mathrm{ng} / \mathrm{ml}$ & $\begin{array}{l}\text { Within } 48 \mathrm{~h} \text { of treatment start, } \\
\text { then every } 48 \mathrm{~h} \text { during } \\
\text { treatment }\end{array}$ & $\begin{array}{l}\text { Correlation between TnT } \\
\text { increase and median LVEF } \\
\text { decline }\end{array}$ \\
\hline $\begin{array}{l}\text { Sandri et al. } \\
\text { (63) }\end{array}$ & Various & 179 & $\mathrm{HDC}$ & 1 & $0.08 \mathrm{ng} / \mathrm{ml}$ & $\begin{array}{l}\text { Before, and } 0,12,24,36, \text { and } \\
72 \mathrm{~h} \text { after every cycle }\end{array}$ & $\begin{array}{l}\text { Tnl increase predicted } \\
\text { subsequent LVEF decline }\end{array}$ \\
\hline $\begin{array}{l}\text { Cardinale et al. } \\
(62)\end{array}$ & Various & 703 & $\mathrm{HDC}$ & 1 & $0.08 \mathrm{ng} / \mathrm{ml}$ & $\begin{array}{l}\text { Before, and } 0,12,24,36 \text {, and } \\
72 \mathrm{~h} \text { after every cycle, and } \\
1 \text { month after treatment }\end{array}$ & $\begin{array}{l}\text { Persistent Tnl positivity } \\
\text { predicted for subsequent } \\
\text { LVEF decline }\end{array}$ \\
\hline $\begin{array}{l}\text { Kilickap et al. } \\
\text { (69) }\end{array}$ & Various & 41 & ACs & $\mathrm{T}$ & $0.01 \mathrm{ng} / \mathrm{ml}$ & $\begin{array}{l}\text { Baseline, after first and last } \\
\text { cycle }\end{array}$ & $\begin{array}{l}\text { Correlation between TnT } \\
\text { increase and diastolic } \\
\text { dysfunction (E/A ratio) }\end{array}$ \\
\hline Perik et al. (70) & Breast cancer & 17 & ACs and $T$ & । & $0.1 \mathrm{~g} / \mathrm{l}$ & $\begin{array}{l}\text { Before, and throughout } \mathrm{T} \\
\text { therapy }\end{array}$ & $\begin{array}{l}\text { NoTnl elevations in 15/16 } \\
\text { patients }\end{array}$ \\
\hline $\begin{array}{l}\text { Dodos et al. } \\
\text { (71) }\end{array}$ & Various & 100 & ACs & $T$ & $0.1 \mathrm{ng} / \mathrm{ml}$ & $\begin{array}{l}\text { After first dose, last dose, and } \\
1,6,12 \text { months after last dose }\end{array}$ & NoTnT elevations detected \\
\hline $\begin{array}{l}\text { Kozak et al. } \\
(72)\end{array}$ & $\begin{array}{l}\text { Lung and } \\
\text { esophageal CA }\end{array}$ & 30 & ChemoRT & $T$ & & $\begin{array}{l}\text { Baseline, } 2 \text { weeks after start } \\
\text { of treatment and after }\end{array}$ & $\begin{array}{l}\text { TnT undetectable in 29/30 } \\
\text { patients }\end{array}$ \\
\hline Cil et al. (73) & Breast cancer & 33 & ACs & । & & $\begin{array}{l}\text { Before and after } \\
\text { chemotherapy }\end{array}$ & $\begin{array}{l}\text { No correlation between Tnl } \\
\text { and LVEF decline }\end{array}$ \\
\hline $\begin{array}{l}\text { Mavinkurve- } \\
\text { Groothuis } \\
\text { et al. (74) }\end{array}$ & $\begin{array}{l}\text { Various } \\
\text { pediatric }\end{array}$ & 122 & ACs & $\mathrm{T}$ & $0.01 \mathrm{ng} / \mathrm{ml}$ & Once, with imaging & $\begin{array}{l}\text { No patients with elevated TnT } \\
\text { levels }\end{array}$ \\
\hline
\end{tabular}


Table 1 | Continued

\begin{tabular}{|c|c|c|c|c|c|c|c|}
\hline Reference & Population & $\mathbf{N}$ & Treatment & Tn type & Cutoff & Troponin evaluations & Results and conclusions \\
\hline $\begin{array}{l}\text { Cardinale et al. } \\
\text { (75) }\end{array}$ & Breast cancer & 251 & ACs and $T$ & 1 & $0.08 \mathrm{ng} / \mathrm{ml}$ & $\begin{array}{l}\text { Before T, every } 3 \text { months } \\
\text { during treatment, } 1 \text { year after } \\
\text { start, every } 6 \text { months }\end{array}$ & $\begin{array}{l}\text { Elevated Tnl values are an } \\
\text { independent predictor of } \\
\text { cardiotoxicity, and LVEF } \\
\text { recovery }\end{array}$ \\
\hline $\begin{array}{l}\text { Nellessen } \\
\text { et al. (76) }\end{array}$ & $\begin{array}{l}\text { Lung and } \\
\text { breast CA }\end{array}$ & 23 & $\mathrm{RT}$ & I & $0.03 \mathrm{ng} / \mathrm{ml}$ & $\begin{array}{l}\text { Before RT, every week during } \\
\text { RT for } 4-6 \text { weeks }\end{array}$ & $\begin{array}{l}\text { Log-transformed Tnl } \\
\text { increased during treatment }\end{array}$ \\
\hline $\begin{array}{l}\text { Fallah-Rad } \\
\text { et al. (51) }\end{array}$ & Breast cancer & 42 & ACs and $\mathrm{T}$ & $\mathrm{T}$ & & $\begin{array}{l}\text { Before chemotherapy, before } \\
\text { T, and } 3,6,9 \text {, and } 12 \text { months } \\
\text { after start of } T\end{array}$ & $\begin{array}{l}\text { No change in } \mathrm{TnT} \text { values over } \\
\text { time }\end{array}$ \\
\hline Feola et al. (77) & Breast cancer & 53 & $\mathrm{ACs}$ & 1 & $0.03 \mathrm{ng} / \mathrm{ml}$ & $\begin{array}{l}\text { Baseline, after } 1 \text { month, } 1 \text {, } \\
\text { and } 2 \text { years }\end{array}$ & $\begin{array}{l}\text { Tnl concentrations elevated at } \\
1 \text { month, then returned to } \\
\text { normal }\end{array}$ \\
\hline Goel et al. (78) & Breast cancer & 36 & ACs and $\mathrm{T}$ & 1 & $0.20 \mathrm{ng} / \mathrm{ml}$ & $\begin{array}{l}\text { Baseline, before and } 24 \mathrm{~h} \\
\text { after } \mathrm{T}\end{array}$ & $\begin{array}{l}\text { No elevated Tnl values } \\
\text { throughout }\end{array}$ \\
\hline $\begin{array}{l}\text { Morris et al. } \\
\text { (79) }\end{array}$ & Breast cancer & 95 & ACs and $\mathrm{T}$ & I & $\begin{array}{l}0.04- \\
0.06 \mathrm{ng} / \mathrm{ml}\end{array}$ & $\begin{array}{l}\text { Every } 2 \text { weeks during } \\
\text { treatment, then at } 6,9 \text {, and } \\
18 \text { months }\end{array}$ & $\begin{array}{l}\text { Elevated Tnl values preceded } \\
\text { maximal LVEF decline, but no } \\
\text { relationship with max LVEF } \\
\text { decline }\end{array}$ \\
\hline $\begin{array}{l}\text { Romano et al. } \\
\text { (80) }\end{array}$ & Breast cancer & 92 & $\mathrm{ACs}$ & I & $\begin{array}{l}5 \text { or } \\
0.08 \mathrm{ng} / \mathrm{ml} \\
\text { (age } \leq 50 \text { or } \\
>50 \text { ) }\end{array}$ & $\begin{array}{l}\text { Every } 2 \text { weeks during } \\
\text { treatment, then at } 3,6 \text {, and } \\
12 \text { months }\end{array}$ & $\begin{array}{l}\text { No correlation between Tnl } \\
\text { change and subsequent LV } \\
\text { impairment }\end{array}$ \\
\hline $\begin{array}{l}\text { Sawaya et al. } \\
\text { (81) }\end{array}$ & Breast cancer & 43 & ACs and $T$ & 1 & $0.015 \mathrm{ng} / \mathrm{ml}$ & $\begin{array}{l}\text { Baseline, } 3 \text { and } 6 \text { months } \\
\text { after chemotherapy }\end{array}$ & $\begin{array}{l}\text { Elevated Tnl at } 3 \text { months } \\
\text { predicted for cardiotoxicity } \\
\text { within } 6 \text { months }\end{array}$ \\
\hline $\begin{array}{l}\text { D'Errico et al. } \\
\text { (82) }\end{array}$ & Breast cancer & 60 & ChemoRT & 1 & $0.07 \mathrm{ng} / \mathrm{ml}$ & Before, and after RT & $\begin{array}{l}\text { No elevated Tnl } \\
\text { concentrations }\end{array}$ \\
\hline $\begin{array}{l}\text { Garrone et al. } \\
\text { (83) }\end{array}$ & Breast cancer & 50 & $\mathrm{ACs}$ & I & $0.03 \mathrm{ng} / \mathrm{ml}$ & $\begin{array}{l}\text { Baseline, 5, 16, and } \\
28 \text { months after }\end{array}$ & $\begin{array}{l}\text { Tnl kinetics correlated with } \\
\text { LVEF decline }\end{array}$ \\
\hline $\begin{array}{l}\text { Lipshultz et al. } \\
\text { (84) }\end{array}$ & ALL & 156 & $\mathrm{ACs}$ & $\mathrm{T}$ & $0.01 \mathrm{ng} / \mathrm{ml}$ & $\begin{array}{l}\text { Before, and daily during } \\
\text { induction, and after treatment }\end{array}$ & $\begin{array}{l}\text { Lower incidence of } \\
\text { detectable TnT during } \\
\text { treatment with dexrazoxane }\end{array}$ \\
\hline $\begin{array}{l}\text { Onitilo et al. } \\
\text { (85) }\end{array}$ & Breast cancer & 54 & $\begin{array}{l}\text { Taxanes } \\
\text { and T }\end{array}$ & I & $0.1 \mathrm{ng} / \mathrm{ml}$ & $\begin{array}{l}\text { Baseline, and every } 3 \text { weeks } \\
\text { during treatment }\end{array}$ & Tnl undetectable throughout \\
\hline $\begin{array}{l}\text { Sawaya et al. } \\
\text { (86) }\end{array}$ & Breast cancer & 81 & ACs and $\mathrm{T}$ & I & $30 \mathrm{pg} / \mathrm{ml}$ & $\begin{array}{l}\text { Before, every } 3 \text { months } \\
\text { during, and after } T \text { treatment }\end{array}$ & $\begin{array}{l}\text { Elevated Tnl values at end of } \\
\text { treatment predictive of } \\
\text { subsequent cardiotoxicity }\end{array}$ \\
\hline $\begin{array}{l}\text { Sherief et al. } \\
\text { (87) }\end{array}$ & $\begin{array}{l}\text { Acute } \\
\text { leukemias }\end{array}$ & 50 & $\mathrm{ACs}$ & $\mathrm{T}$ & $0.01 \mathrm{ng} / \mathrm{ml}$ & Once, with imaging & No elevated TnT values \\
\hline $\begin{array}{l}\text { Erven et al. } \\
\text { (88) }\end{array}$ & Breast cancer & 72 & $\mathrm{RT}$ & 1 & $0.13 \mathrm{ng} / \mathrm{ml}$ & Before and after RT & $\begin{array}{l}\text { Higher Tnl values in L-sided } \\
\text { breast patients }\end{array}$ \\
\hline Ky et al. (89) & Breast cancer & 78 & ACs and $T$ & 1 & $121.8 \mathrm{ng} / \mathrm{ml}$ & $\begin{array}{l}\text { Baseline, } 3 \text { and } 6 \text { months } \\
\text { after start of chemotherapy }\end{array}$ & $\begin{array}{l}\text { Interval change in Tnl } \\
\text { predicted cardiotoxicity }\end{array}$ \\
\hline
\end{tabular}

Tn, troponin; AC, anthracycline; RT, radiation therapy; HDC, high-dose chemotherapy; T, trastuzumab; LVEF, left ventricular ejection fraction; ALL, acute lymphoblastic leukemia. 
as the cutoff concentration, they found TnI alone predicted subsequent cardiotoxicity with PPV of $44 \%$ and NPV of $77 \%$ (86). Adding peak systolic longitudinal strain of $<19 \%$ improved the specificity of the model, yielding a PPV of $67 \%$ and NPV of $77 \%$. Interestingly, baseline LVEF at the time of AC completion did not predict for future cardiotoxicity. Though the majority of studies evaluating troponins in trastuzumab-induced cardiac damage have demonstrated its usefulness, several experiences have been negative (51,77-79).

Despite abundant literature on radiation-induced cardiac injury, troponins have yet to demonstrate any clinical utility. Studies in which considerable numbers of patients were treated with RT as a single modality are relatively scarce. Of those that try to isolate the effect of radiotherapy, none have been able draw clinically valuable conclusions regarding the value of troponin in predicting radiation-induced cardiotoxicity $(64,72,82)$. In fact, of four studies that included patients with breast, lung, and esophageal cancer, only one saw significantly elevated TnI concentrations after RT (88).

\section{NATRIURETIC PEPTIDES}

Natriuretic peptides, such atrial natriuretic peptide (ANP), brain natriuretic peptide (BNP), and its amino-terminal component (NT-proBNP) have been widely investigated and used in acute and chronic heart failure for diagnosis and prognosis. In response to increased wall stress, BNP is synthesized by ventricular cardiomyocytes as a 134-amino acid (aa) pre-pro peptide, which is then cleaved into a 108-aa precursor molecule (proBNP). Upon release, proBNP is cleaved into an inactive $\mathrm{N}$-terminal component (NT-proBNP) and the 32-residue active hormone BNP. To counteract volume overload, biological actions of BNP include natriuresis, vasodilation, and suppression of sympathetic activity (91). Chronic elevations in BNP reflect increased LV wall stress diastolic pressure, and volume overload (92, 93). Moreover, NT-proBNP concentrations have been related to LVEF values and the severity of hearth failure (94). Thus, using natriuretic peptides to risk-stratify patients with potential cardiotoxicity would intuitively be an attractive strategy, as they represent hemodynamic aberrancy and ventricular remodeling, and can appear prior to symptomatic heart failure and LVEF decline (95).

A large number of studies have described significant BNP and NT-proBNP elevations with doxorubicin, epirubicin, trastuzumab, and thoracic irradiation, either alone in combination therapy, though substantially fewer have found clinical relevant relationships (Table 2 ). One early study that established the predictive value of NT-proBNP examined its role in patients with various advanced malignancies treated with high-dose ACbased chemotherapy (63). Sandri et al. measured NT-proBNP at baseline, and then at five time points within $72 \mathrm{~h}$ of completing each treatment cycle. Persistent NT-proBNP measurements predicted for the development of cardiac dysfunction at 12 months when quantified by three LV diastolic indices. The predictive value of early NT-proBNP rises was also seen with a cohort of breast cancer patients with doxorubicin to a cumulative dose of $300 \mathrm{mg} / \mathrm{m}^{2}$ (80). Post-chemotherapy NT-proBNP increases were related to subsequent LVEF decline $(r=0.7, p \leq 0.001)$.
An ROC analysis using a cutoff of $>36 \%$ NT-proBNP increase from baseline to peak predicted LV impairment at 12 months after therapy with $79.2 \%$ sensitivity and specificity. Similar correlations between NT-proBNP elevations and LVEF values in the setting of breast cancer treated with moderate dose epirubicin and non-Hodgkin lymphoma patients after six cycles of CHOP chemotherapy $(96,97)$.

Though early BNP increases have been the focus of many studies for its predictive capabilities, BNP levels can remain elevated up to 2 years after AC-based treatment. This suggests that persistent neurohormonal activation, independent of acute tissue toxicity, is one underlying mechanism of late-onset AC-induced cardiotoxicity (77). BNP monitoring during chemotherapy has also been linked to significant diastolic dysfunction with CHOP. A study by Nousiainen et al. revealed associations between BNP, fractional shortening (FS) $(p=0.04)$, E/A ratio $(p=0.006)$, and trend to significance with LA diameter $(p=0.062)$ (99). Studies involving AC in the adult population have also seen substantial increases in NTproBNP with no significant interactions with echocardiographic or clinical outcomes $(71,73,98,100)$.

While there has been great interest in validating natriuretic peptides as predictors of cardiotoxicity in the pediatric population, studies in this setting have seen mixed results. NT-proBNP has been shown to be an effect indicator of cardioprotective interventions (84). Specifically, children with ALL were randomized to receive doxorubicin with or without dexrazoxane, an effective free radical scavenger. Lipshultz et al. discovered drastically reduced NT-proBNP concentrations after dexrazoxane treatment ( 47 vs. $20 \%, p=0.07$ ). Increased NT-proBNP in the first 90 days of treatment also predicted abnormal LV thickness-todimension ratios, suggestive of late-onset LV remodeling. Germanakis et al. evaluated BNP nearly 4 years after AC treatment to find an association between NT-proBNP with LV mass reductions $(p=0.003)$ in asymptomatic survivors (103). Lastly, NTproBNP concentrations have been consistently identified as a proxy for cumulative AC dose in survivors of childhood cancers $(74,105,108)$.

The experience with natriuretic peptides corroborates largescale studies that have shown the clinic onset of RT-induced cardiotoxicity can occur years after therapy. Significant NT-proBNP elevations have been detected as early as 9 months, and as late as 6.7 years after radiation to the thorax for breast and esophageal cancer $(82,101,106)$. In 64 patients with esophageal cancer treated to median dose of $60 \mathrm{~Gy}$, increased NT-proBNP concentrations were found beginning at 9 months (when compared to baseline), and persisted at 24 months after radiotherapy. Additionally, NT-proBNP may be an early indicator of radiation-induced myocardial damage. Substantially, higher natriuretic peptide concentrations were found in subjects with high F-fluorodeoxyglucose (FDG) accumulation on positron emission tomography (PET) corresponding to the irradiated fields (106). Similarly, NT-proBNP has also been linked to cardiac doses in left-sided breast cancer. D'Errico et al. found significant associations between NT-proBNP and $\mathrm{V}_{3 \mathrm{~Gy}}$ (volume receiving at least $3 \mathrm{~Gy}$ ), and two ratios for the heart: $D_{15 \mathrm{~cm} 3} / D_{\text {mean }}$ and $D_{15 \mathrm{~cm} 3} / D_{50 \%}$ (where $D_{\text {mean }}$ is the mean dose, $\mathrm{D}_{50 \%}$ is the median dose, and $\mathrm{D}_{15 \mathrm{~cm}^{3}}$ is the minimum isodose received by $\left.15 \mathrm{~cm}^{3}\right)(82)$. 
Table 2 | Role of natriuretic peptides in the evaluation of chemotherapy and radiation-induced cardiotoxicity

\begin{tabular}{|c|c|c|c|c|c|c|c|}
\hline Reference & Population & $\mathbf{N}$ & Treatment & BNP type & Cutoff & BNP evaluations & Results and conclusions \\
\hline $\begin{array}{l}\text { Nousiainen } \\
\text { et al. (99) }\end{array}$ & $\begin{array}{l}\text { Non- } \\
\text { Hodgkin } \\
\text { lymphoma }\end{array}$ & 28 & $\mathrm{CHOP}$ & BNP & $227 \mathrm{pmol} / \mathrm{l}$ & $\begin{array}{l}\text { Baseline, after every } \\
\text { cycle, and } 4 \text { weeks } \\
\text { after last cycle }\end{array}$ & $\begin{array}{l}\text { Correlation between BNP increases and } \\
\text { parameters of diastolic function (FS and } \\
\text { PFR) }\end{array}$ \\
\hline $\begin{array}{l}\text { Daugaard } \\
\text { et al. (100) }\end{array}$ & Various & 107 & ACs & BNP & & $\begin{array}{l}\text { Before, and at } \\
\text { various points during } \\
\text { treatment }\end{array}$ & $\begin{array}{l}\text { BNP correlation with decreased LVEF, } \\
\text { but baseline and BNP change could not } \\
\text { predict LVEF decline }\end{array}$ \\
\hline $\begin{array}{l}\text { Perik et al. } \\
\text { (101) }\end{array}$ & $\begin{array}{l}\text { Breast } \\
\text { cancer }\end{array}$ & 54 & $\begin{array}{l}\text { ACs and } \\
\text { RT }\end{array}$ & $\begin{array}{l}\text { NT- } \\
\text { proBNP }\end{array}$ & $10 \mathrm{pmol} / \mathrm{l}$ & $\begin{array}{l}\text { Median } 2.7 \text { and } \\
6.5 \text { years after } \\
\text { chemotherapy }\end{array}$ & $\begin{array}{l}\text { BNP increased with time and was } \\
\text { related to dose; cardiotoxic effects } \\
\text { develop over years }\end{array}$ \\
\hline $\begin{array}{l}\text { Germanakis } \\
\text { et al. (103) }\end{array}$ & $\begin{array}{l}\text { Pediatric } \\
\text { cancers }\end{array}$ & 19 & ACs & $\begin{array}{l}\text { NT- } \\
\text { proBNP }\end{array}$ & $0.2 \mathrm{pmol} / \mathrm{ml}$ & $\begin{array}{l}\text { Mean } 3.9 \text { years after } \\
\text { chemotherapy }\end{array}$ & $\begin{array}{l}\text { Correlation between NT-proBNP and LV } \\
\text { mass decrease }\end{array}$ \\
\hline $\begin{array}{l}\text { Perik et al. } \\
(70)\end{array}$ & $\begin{array}{l}\text { Breast } \\
\text { cancer }\end{array}$ & 17 & $\begin{array}{l}\text { ACs } \\
\text { and T }\end{array}$ & $\begin{array}{l}\text { NT- } \\
\text { proBNP }\end{array}$ & $125 \mathrm{ng} / \mathrm{l}$ & $\begin{array}{l}\text { Baseline and } \\
\text { throughout } T \\
\text { treatment }\end{array}$ & $\begin{array}{l}\text { Higher pre-treatment NT-proBNP values } \\
\text { in those who developed HF during } \\
\text { treatment }\end{array}$ \\
\hline $\begin{array}{l}\text { Kouloubinis } \\
\text { et al. (97) }\end{array}$ & $\begin{array}{l}\text { Breast } \\
\text { cancer }\end{array}$ & 40 & $\mathrm{ACs}$ & $\begin{array}{l}\text { NT- } \\
\text { proBNP }\end{array}$ & & $\begin{array}{l}\text { Before and after } \\
\text { chemotherapy }\end{array}$ & $\begin{array}{l}\text { Correlation between NT-proBNP } \\
\text { increase and LVEF decline }\end{array}$ \\
\hline $\begin{array}{l}\text { Dodos et al. } \\
\text { (71) }\end{array}$ & Various & 100 & ACs & $\begin{array}{l}\text { NT- } \\
\text { proBNP }\end{array}$ & $\begin{array}{l}153 \text { or } 227 \mathrm{ng} / \mathrm{l} \\
\text { for } \mathrm{M} \leq 50 \text { or } \\
>50 ; 88 \text { or } \\
334 \mathrm{ng} / \mathrm{l} \text { for } \mathrm{F} \\
\leq 50 \text { or }>50\end{array}$ & $\begin{array}{l}\text { After first dose, last } \\
\text { dose, and 1, 6, and } \\
12 \text { months after last } \\
\text { dose }\end{array}$ & $\begin{array}{l}\text { No significant increase in NT-proBNP } \\
\text { with treatment; cannot replace serial } \\
\text { ECHO for monitoring of AC-induced } \\
\text { cardiotoxicity }\end{array}$ \\
\hline $\begin{array}{l}\text { Kozak et al. } \\
\text { (72) }\end{array}$ & $\begin{array}{l}\text { Lung and } \\
\text { esophageal } \\
\text { CA }\end{array}$ & 30 & ChemoRT & $\begin{array}{l}\text { NT- } \\
\text { proBNP }\end{array}$ & & $\begin{array}{l}\text { Baseline, after } \\
2 \text { weeks of RT, and } \\
\text { after RT end }\end{array}$ & $\begin{array}{l}\text { No change in NT-proBNP during } \\
\text { treatment }\end{array}$ \\
\hline $\begin{array}{l}\text { Cil et al. } \\
(73)\end{array}$ & $\begin{array}{l}\text { Breast } \\
\text { cancer }\end{array}$ & 33 & ACs & $\begin{array}{l}\text { NT- } \\
\text { proBNP }\end{array}$ & $110 \mathrm{pg} / \mathrm{ml}$ & $\begin{array}{l}\text { Before and after } \\
\text { chemotherapy }\end{array}$ & $\begin{array}{l}\text { Despite association, pre-chemo } \\
\text { NT-proBNP did not predict for later LVEF }\end{array}$ \\
\hline $\begin{array}{l}\text { ElGhandour } \\
\text { et al. (96) }\end{array}$ & $\begin{array}{l}\text { Non- } \\
\text { Hodgkin } \\
\text { lymphoma }\end{array}$ & 40 & $\mathrm{CHOP}$ & BNP & & $\begin{array}{l}\text { Before first cycle and } \\
\text { after sixth cycle of } \\
\text { chemotherapy }\end{array}$ & $\begin{array}{l}\text { Correlation between BNP values after } \\
\text { chemotherapy and LVEF }\end{array}$ \\
\hline
\end{tabular}


Table 2 | Continued

\begin{tabular}{|c|c|c|c|c|c|c|c|}
\hline Reference & Population & $\mathbf{N}$ & Treatment & BNP type & Cutoff & BNP evaluations & Results and conclusions \\
\hline $\begin{array}{l}\text { Mavinkurve- } \\
\text { Groothuis } \\
\text { et al. (74) }\end{array}$ & $\begin{array}{l}\text { Pediatric } \\
\text { cancers }\end{array}$ & 122 & $\mathrm{ACs}$ & $\begin{array}{l}\text { NT- } \\
\text { proBNP }\end{array}$ & $\begin{array}{l}10 \mathrm{pmol} / \mathrm{l}(\mathrm{M}), \\
18 \mathrm{pmol} / \mathrm{l}(\mathrm{F}), \\
\text { age-adjusted } \\
\text { in children } \\
(107)\end{array}$ & Once, with imaging & $\begin{array}{l}\text { NT-proBNP levels related to cumulative } \\
\text { AC dose }\end{array}$ \\
\hline $\begin{array}{l}\text { Nellessen } \\
\text { et al. (76) }\end{array}$ & $\begin{array}{l}\text { Lung and } \\
\text { breast CA }\end{array}$ & 23 & $\mathrm{RT}$ & $\begin{array}{l}\text { NT- } \\
\text { proBNP }\end{array}$ & $100 \mathrm{pg} / \mathrm{ml}$ & $\begin{array}{l}\text { Before RT, every } \\
\text { week during RT for } \\
\text { 4-6 weeks }\end{array}$ & $\begin{array}{l}\text { Log-transformed NT-proBNP increased } \\
\text { during treatment }\end{array}$ \\
\hline $\begin{array}{l}\text { Fallah-Rad } \\
\text { et al. (51) }\end{array}$ & $\begin{array}{l}\text { Breast } \\
\text { cancer }\end{array}$ & 42 & $\begin{array}{l}\text { ACs } \\
\text { and } \mathrm{T}\end{array}$ & $\begin{array}{l}\text { NT- } \\
\text { proBNP }\end{array}$ & & $\begin{array}{l}\text { Before } \\
\text { chemotherapy, } \\
\text { before } T \text {, and } 3,6,9, \\
\text { and } 12 \text { months after } \\
\text { start of } T\end{array}$ & $\begin{array}{l}\text { No change in NT-proBNP values over } \\
\text { time }\end{array}$ \\
\hline $\begin{array}{l}\text { Feola et al. } \\
(77)\end{array}$ & $\begin{array}{l}\text { Breast } \\
\text { cancer }\end{array}$ & 53 & $\mathrm{ACs}$ & $\begin{array}{l}\text { NT- } \\
\text { proBNP }\end{array}$ & $5 \mathrm{pg} / \mathrm{ml}$ & $\begin{array}{l}\text { Baseline, after } \\
1 \text { month, } 1 \text {, and } \\
2 \text { years }\end{array}$ & $\begin{array}{l}\text { NT-proBNP increased acutely with } \\
\text { treatment, and in patients with systolic } \\
\text { dysfunction }\end{array}$ \\
\hline $\begin{array}{l}\text { Goel et al. } \\
(78)\end{array}$ & $\begin{array}{l}\text { Breast } \\
\text { cancer }\end{array}$ & 36 & $\begin{array}{l}\text { ACs } \\
\text { and } T\end{array}$ & $\begin{array}{l}\text { NT- } \\
\text { proBNP }\end{array}$ & $\begin{array}{l}110 \mathrm{pg} / \mathrm{ml} \text { (age } \\
<75) \\
589 \mathrm{pg} / \mathrm{ml} \text { (age } \\
>75)\end{array}$ & $\begin{array}{l}\text { Baseline, before and } \\
24 \mathrm{~h} \text { after } \mathrm{T}\end{array}$ & $\begin{array}{l}\text { No change in NT-proBNP with } \\
\text { trastuzumab }\end{array}$ \\
\hline $\begin{array}{l}\text { Romano } \\
\text { et al. (80) }\end{array}$ & $\begin{array}{l}\text { Breast } \\
\text { cancer }\end{array}$ & 92 & $\mathrm{ACs}$ & $\begin{array}{l}\text { NT- } \\
\text { proBNP }\end{array}$ & $\begin{array}{l}153 \mathrm{pg} / \mathrm{ml} \text { (age } \\
\leq 50) \\
222 \mathrm{pg} / \mathrm{ml} \text { (age } \\
>50 \text { ) }\end{array}$ & $\begin{array}{l}\text { Every } 2 \text { weeks } \\
\text { during treatment, } \\
\text { then at } 3,6 \text {, and } \\
12 \text { months }\end{array}$ & $\begin{array}{l}\text { Interval change in NT-proBNP predicated } \\
\text { for LV impairment at 3, 6, and } 12 \text { months }\end{array}$ \\
\hline $\begin{array}{l}\text { Sawaya } \\
\text { et al. (81) }\end{array}$ & $\begin{array}{l}\text { Breast } \\
\text { cancer }\end{array}$ & 43 & $\begin{array}{l}\text { ACs } \\
\text { and T }\end{array}$ & $\begin{array}{l}\text { NT- } \\
\text { proBNP }\end{array}$ & $125 \mathrm{pg} / \mathrm{ml}$ & $\begin{array}{l}\text { Baseline, } 3 \text { and } \\
6 \text { months after } \\
\text { chemotherapy }\end{array}$ & $\begin{array}{l}\text { No relation between NT-proBNP levels } \\
\text { before and after treatment and LVEF } \\
\text { change }\end{array}$ \\
\hline $\begin{array}{l}\text { D'Errico } \\
\text { et al. (82) }\end{array}$ & $\begin{array}{l}\text { Breast } \\
\text { cancer }\end{array}$ & 60 & ChemoRT & $\begin{array}{l}\text { NT- } \\
\text { proBNP }\end{array}$ & $125 \mathrm{pg} / \mathrm{ml}$ & Before, and after RT & $\begin{array}{l}\text { Correlation between NT-proBNP, } V_{3 G y} \text { for } \\
\text { the heart, } D_{15 \mathrm{~cm}^{2}} / \mathrm{D}_{\text {mean }} \text { and } \\
\mathrm{D}_{15 \mathrm{~cm}^{3}} / \mathrm{D}_{50 \%}\end{array}$ \\
\hline $\begin{array}{l}\text { Lipshultz } \\
\text { et al. (84) }\end{array}$ & $A L L$ & 156 & $\mathrm{ACs}$ & $\begin{array}{l}\text { NT- } \\
\text { proBNP }\end{array}$ & $\begin{array}{l}150 \mathrm{pg} / \mathrm{ml} \text { (age } \\
<1), 100 \mathrm{pg} / \mathrm{ml} \\
\text { (age } \geq 1 \text { ) }\end{array}$ & $\begin{array}{l}\text { Before, and daily } \\
\text { during induction, and } \\
\text { after treatment }\end{array}$ & $\begin{array}{l}\text { Correlation between NT-proBNP and } \\
\text { change in LV thickness-to-dimension } \\
\text { ratio } 4 \text { years later }\end{array}$ \\
\hline $\begin{array}{l}\text { Mladosievicova } \\
\text { et al. (108) }\end{array}$ & $\begin{array}{l}\text { Childhood } \\
\text { leukemias }\end{array}$ & 69 & $\mathrm{ACs}$ & $\begin{array}{l}\text { NT- } \\
\text { proBNP }\end{array}$ & $\begin{array}{l}105 \mathrm{pg} / \mathrm{ml}(\mathrm{F}) \\
75 \mathrm{pg} / \mathrm{ml}(\mathrm{M})\end{array}$ & $\begin{array}{l}\text { Median } 11 \text { years } \\
\text { after treatment }\end{array}$ & $\begin{array}{l}\text { Increased NT-proBNP with exposure to } \\
\text { ACs }\end{array}$ \\
\hline $\begin{array}{l}\text { Onitilo et al. } \\
\text { (85) }\end{array}$ & $\begin{array}{l}\text { Breast } \\
\text { cancer }\end{array}$ & 54 & $\begin{array}{l}\text { Taxanes } \\
\text { and T }\end{array}$ & BNP & $200 \mathrm{pg} / \mathrm{ml}$ & $\begin{array}{l}\text { Baseline, and every } \\
3 \text { weeks during } \\
\text { treatment }\end{array}$ & $\begin{array}{l}\text { No correlation between elevated BNP } \\
\text { values and cardiotoxicity }\end{array}$ \\
\hline $\begin{array}{l}\text { Pongprot } \\
\text { et al. (90) }\end{array}$ & $\begin{array}{l}\text { Pediatric } \\
\text { cancers }\end{array}$ & 30 & $\mathrm{ACs}$ & $\begin{array}{l}\text { NT- } \\
\text { proBNP }\end{array}$ & $\begin{array}{l}\text { Age-adjusted } \\
(109)\end{array}$ & Once, with imaging & $\begin{array}{l}\text { Correlation between NT-pro BNP values } \\
\text { and FS and LVEF }\end{array}$ \\
\hline $\begin{array}{l}\text { Sawaya } \\
\text { et al. (86) }\end{array}$ & $\begin{array}{l}\text { Breast } \\
\text { cancer }\end{array}$ & 81 & $\begin{array}{l}\mathrm{ACS} \\
\text { and } \mathrm{T}\end{array}$ & $\begin{array}{l}\text { NT- } \\
\text { proBNP }\end{array}$ & $125 \mathrm{pg} / \mathrm{ml}$ & $\begin{array}{l}\text { Before, every } \\
3 \text { months during, and } \\
\text { after } T \text { treatment }\end{array}$ & $\begin{array}{l}\text { NT-proBNP did not change with } \\
\text { treatment }\end{array}$ \\
\hline $\begin{array}{l}\text { Sherief } \\
\text { et al. (87) }\end{array}$ & $\begin{array}{l}\text { Acute } \\
\text { leukemias }\end{array}$ & 50 & $\mathrm{ACs}$ & $\begin{array}{l}\text { NT- } \\
\text { proBNP }\end{array}$ & $\begin{array}{l}\text { Age-adjusted } \\
(107)\end{array}$ & Once, with imaging & $\begin{array}{l}\text { NT-proBNP linked to AC dose and } \\
\text { abnormal tissue Doppler imaging } \\
\text { parameters }\end{array}$ \\
\hline
\end{tabular}


Table 2 | Continued

\begin{tabular}{|c|c|c|c|c|c|c|c|}
\hline Reference & Population & $\mathbf{N}$ & Treatment & BNP type & Cutoff & BNP evaluations & Results and conclusions \\
\hline $\begin{array}{l}\text { Kittiwarawut } \\
\text { et al. (110) }\end{array}$ & $\begin{array}{l}\text { Breast } \\
\text { cancer }\end{array}$ & 52 & $\mathrm{ACs}$ & $\begin{array}{l}\text { NT- } \\
\text { proBNP }\end{array}$ & $45 \mathrm{pg} / \mathrm{ml}$ & $\begin{array}{l}\text { Baseline, and end of } \\
\text { fourth cycle }\end{array}$ & Correlation between NT-proBNP and FS \\
\hline $\begin{array}{l}\text { Ky et al. } \\
\text { (89) }\end{array}$ & $\begin{array}{l}\text { Breast } \\
\text { cancer }\end{array}$ & 78 & $\begin{array}{l}\text { ACs } \\
\text { and } \mathrm{T}\end{array}$ & $\begin{array}{l}\text { NT- } \\
\text { proBNP }\end{array}$ & & $\begin{array}{l}\text { Baseline, } 3 \text { and } \\
6 \text { months after start } \\
\text { of chemotherapy }\end{array}$ & $\begin{array}{l}\text { No relationship between NT-proBNP } \\
\text { values and cardiotoxicity }\end{array}$ \\
\hline
\end{tabular}

BNP, brain natriuretic peptide; NT, N-terminal; AC, anthracycline; RT, radiation therapy; HDC, high-dose chemotherapy; T, trastuzumab; LVEF, left ventricular ejection fraction; HF, heart failure; $A L L$, acute lymphoblastic leukemia; FS, fractional shortening; PFR, peak filling rate.

The role of NT-proBNP in predicting trastuzumab-induced cardiac dysfunction has been evaluated in five recent studies. Higher pre-treatment (immediately post-chemotherapy) NTproBNP concentrations were found in patients with metastatic breast cancer who developed symptomatic heart failure during treatment $(p=0.009)$ (70). The other four failed to find any meaningful relationship between BNP or its interval changes with measures of cardiac function; often no significant changes were found between pre- and post-treatment NT-proBNP concentrations $(51,78,81,89)$. Concerns regarding sufficient followup and superimposed AC-induce cardiotoxicity make it unclear whether NT-proBNP has any clinical usefulness in predicting trastuzumab-induced cardiac dysfunction.

\section{OTHER PROPOSED MARKERS}

Heart-type fatty acid-binding protein and glycogen phosphorylase isoenzyme BB have been evaluated jointly as potential biomarkers of cardiac toxicity in several studies. Both GPBB and $\mathrm{H}$-FABP are considered markers of early cardiac injury. GPBB is a cardiac-specific enzyme of glycogenolysis, which provides glucose to cardiac muscle. Because GPBB is released into circulation $2-4 \mathrm{~h}$ after myocardial injury, it may be a sensitive, and early marker of acute coronary syndromes. Moreover, GPBB has been found useful for the risk stratification in acute coronary syndromes, as it is an independent predictor of mortality (111). Similarly, H-FABP is a low molecular weight protein normally found in the cytoplasm, but can be detected within 2-3 h after significant myocardial injury $(112,113)$. In three studies that evaluated GPBB in patients with leukemias and lymphomas, Horacek et al. found approximately $17-21.7 \%$ of patients with elevated GPBB concentrations after either ACbased chemotherapy or a preparative regimen for hematopoietic stem cell transplantation (114-116). Based on threshold values of $7.30 \mu \mathrm{g} / \mathrm{l}$ for GPBB and $4.50 \mu \mathrm{g} / \mathrm{l}$ for H-FABP, no study reported significant elevations in $\mathrm{H}-\mathrm{FABP}$, and only one found a correlation between GPBB elevation and LV diastolic dysfunction via impaired relaxation (114). However, in a cohort of non-Hodgkin lymphoma subjects treated with doxorubicinbased chemotherapy, H-FABP measured $23 \mathrm{~h}$ after the first cycle of CHOP was correlated with LVEF assessed after six cycles $(r=-0.836, p<0.001)$ (96). Though numerous studies have found elevated GPBB after chemotherapy, and one has related H-FABP with subsequent systolic dysfunction, none have yet linked biomarker elevations with clinical outcomes in larger populations, which leaves the clinical relevance of these two ischemic markers unclear.

C-reactive protein is an acute phase protein that is synthesized during an inflammatory response. Its expression is regulated by cytokines such interleukin (IL)-1, IL-6, and tissue necrosis factor- $\alpha(\mathrm{TNF}-\alpha)$. In the context of stable coronary artery disease, myocardial infarction, and congestive heart failure, elevated CRP is predictive of decreased LVEF and diastolic dysfunction (117-119). Using a high-sensitivity (hs) assay in breast cancer patients, hsCRP concentrations $\geq 3 \mathrm{mg} / \mathrm{l}$ predicted impaired LVEF with $92.9 \%$ sensitivity and $45.7 \%$ specificity (PPV, 40.6\%; NPV, 94.1\%). As maximum hsCRP elevations were seen on average 78 days before echocardiographic detection, hsCRP may prove to be effective in identifying patients who are less likely to benefit from more stringent follow-up. While Lipshultz et al. found higher CRP values in survivors of various childhood cancers, regardless of exposure to cardiotoxic treatment with modest correlation with LV mass, wall thickness, and dimension (120), multiple studies have found no clinical value in CRP measurements $(79,84,89)$.

Myeloperoxidase is a proinflammatory enzyme that expressed by polymorphonuclear neutrophils that is indicative of oxidative stress, and involved in lipid peroxidation. It has also been identified for its prognostic value in predicting future cardiovascular events in acute coronary syndromes and adverse outcomes in heart failure $(121,122)$. MPO was identified as one of two predictors of cardiotoxicity in breast cancer patients treated with ACs and Herceptin, from a panel of potential biomarkers including CRP, NTproBNP, growth differentiation factor (GDF)-15, placenta growth factor (PlGF), soluble fms-like tyrosine kinase receptor ( $\mathrm{sFlt}$ )-1, and galectin (gal)-3 (89). Ky et al. found that for patients with 90th percentile MPO interval change from baseline ( $422.6 \mathrm{pmol} / \mathrm{l}$ increase), the probability of CREC cardiotoxicity at 15 months was $34.2 \%$, and the risk of future cardiac toxicity was amplified with each standard deviation increase in MPO concentration (HR 1.34, $p=0.048$ ). When considered jointly with 90th percentile interval TnI elevations, the risk of cardiotoxicity by 15 months was $46.5 \%$.

Nitric oxide is a small molecule generated by NO synthase from $\mathrm{L}$-arginine in numerous cell types, including endothelial cells, platelets, neutrophils, and macrophage (123). NO is a key regulator of cardiomyocyte contractility, and inducible NO synthase has been implicated in the pathophysiology of heart failure and cardiomyopathy $(124,125)$. Dysregulated NO synthesis has been found to be one mechanism involved in doxorubicin-induced cardiotoxicity, as studies in bovine endothelial cells have linked 
redox activation of doxorubicin with endothelial NO synthesis in doxorubicin-induced apoptosis $(126,127)$. NO has been described as a potential marker of subclinical cardiac dysfunction in the pediatric setting. Guler et al. found significantly higher nitrite values in children treated with doxorubicin compared to healthy controls, and in those with abnormal/borderline LVEF and FS values (92.35 vs. $59.26 \mu \mathrm{mol} / \mathrm{l}, p=0.038)(128)$.

\section{CONCLUSION AND FUTURE DIRECTIONS}

Cardiac toxicity associated with cancer treatment is a growing source of significant morbidity and mortality. Current screening practices are suboptimal as they provided limited opportunity to intervene and change the course of disease progression. Serum biomarkers, and especially cardiac troponins in patients treated with HDC, represent an effective method for monitoring cardiac status, and identifying patients who may benefit from early medical intervention. There is also growing evidence for a combined approach in which biomarkers and echocardiograms are co-interpreted.

A discussion of any screening test's validity would be incomplete without considering Wilson and Junger's classic screening criteria (129). Of the 10 criteria, some are evident, such as "the condition sought should be an important health problem." And of the 10 , the two that deserve additional mention here are "there should be an accepted treatment for patients with recognized disease," and "there should be an agreed policy on whom to treat as patients." Both of these questions were addressed by a large randomized study that evaluated the cardioprotective effects of enalapril, an angiotensin-converting-enzyme inhibitor routinely used for congestive heart failure (130). Of 413 patients treated with high-dose ACs in the study, 114 patients developed early increases in TnI and were randomized to receive either enalapril $(n=56)$ or placebo $(n=58)$. In the intervention arm, enalapril was given for 1 year, starting 1 month after chemotherapy. The placebo arm suffered from a significant and progressive decline in LVEF (62.4 vs. 48.3\% at 12 months, $p<0.001$ ), as well as increases in end-diastolic and end-systolic volume. Moreover, the treatment group benefited from a lower incidence of adverse cardiac events (2 vs. 52\%, $p<0.001)$. Other investigators have evaluated the beta-blockers nebivolol and carvedilol in the randomized setting, finding treatment during AC chemotherapy offered significant protection of LVEF in both interventions $(131,132)$. Though investigations are still ongoing, the results accumulated so far suggests cardiotoxicity, if detected early enough, and treated appropriately, is a potentially treatable condition. Additionally, the study populations and criteria used for treatment have provided a foundation for management decisions that can further refined.

As data on the treatment of chemotherapy-induced cardiotoxicity continue to accumulate, the objective of validating and refining biomarker-based screening strategies becomes more and more clear. Because, clinically apparent signs of cardiac injury often occur years after initial therapy, there are few studies that have been able to link early rises in biomarker concentrations with clinical endpoints. Thus, there is a need longer for long-term data to either confirm or refute any meaningful relationship between early biomarker status and long-term cardiac morbidity. Additionally, because the optimal schedule of biomarker assessments remains unclear, the integration of biomarker evaluations into large prospective clinical trials is critical. As the burden of antineoplastic therapy-induced cardiac morbidity increases, so does the need to find effective strategies for risk stratification and management of therapy-induced cardiotoxicity.

\section{REFERENCES}

1. Centers for Disease Control. Prevention. Cancer survivors - United States, 2007. MMWR Morb Mortal Wkly Rep (2011) 60(9):269-72.

2. Dolci A, Dominici R, Cardinale D, Sandri MT, Panteghini M. Biochemical markers for prediction of chemotherapy-induced cardiotoxicity: systematic review of the literature and recommendations for use. Am J Clin Pathol (2008) 130(5):688-95. doi:10.1309/AJCPB66LRIIVMQDR

3. Germanakis I, Anagnostatou N, Kalmanti M. Troponins and natriuretic peptides in the monitoring of anthracycline cardiotoxicity. Pediatr Blood Cancer (2008) 51(3):327-33. doi:10.1002/pbc.21633

4. Mavinkurve-Groothuis AM, Kapusta L, Nir A, Groot-Loonen J. The role of biomarkers in the early detection of anthracycline-induced cardiotoxicity in children: a review of the literature. Pediatr Hematol Oncol (2008) 25(7):655-64. doi:10.1080/08880010802244001

5. Cardinale D, Sandri MT. Role of biomarkers in chemotherapy-induced cardiotoxicity. Prog Cardiovasc Dis (2010) 53(2):121-9. doi:10.1016/j.pcad.2010. 04.002

6. Cardinale D, Salvatici M, Sandri MT. Role of biomarkers in cardioncology. Clin Chem Lab Med (2011) 49(12):1937-48. doi:10.1515/CCLM.2011.692

7. Early Breast Cancer Trialists' Collaborative Group. Effects of chemotherapy and hormonal therapy for early breast cancer on recurrence and 15-year survival: an overview of the randomised trials. Lancet (2005) 365(9472):1687-717. doi:10.1016/S0140-6736(05)66544-0

8. Shan K, Lincoff AM, Young JB. Anthracycline-induced cardiotoxicity. Ann Intern Med (1996) 125(1):47-58. doi:10.7326/0003-4819-125-1-19960701000008

9. Gianni L, Herman EH, Lipshultz SE, Minotti G, Sarvazyan N, Sawyer DB. Anthracycline cardiotoxicity: from bench to bedside. J Clin Oncol (2008) 26(22):3777-84. doi:10.1200/JCO.2007.14.9401

10. Minotti G, Menna P, Salvatorelli E, Cairo G, Gianni L. Anthracyclines: molecular advances and pharmacologic developments in antitumor activity and cardiotoxicity. Pharmacol Rev (2004) 56(2):185-229. doi:10.1124/pr.56.2.6

11. Pai VB, Nahata MC. Cardiotoxicity of chemotherapeutic agents: incidence, treatment and prevention. Drug Saf (2000) 22(4):263-302. doi:10.2165/ 00002018-200022040-00002

12. Smith LA, Cornelius VR, Plummer CJ, Levitt G, Verrill M, Canney P, et al. Cardiotoxicity of anthracycline agents for the treatment of cancer: systematic review and meta-analysis of randomised controlled trials. BMC Cancer (2010) 10:337. doi:10.1186/1471-2407-10-337

13. Von Hoff DD, Rozencweig M, Layard M, Slavik M, Muggia FM. Daunomycininduced cardiotoxicity in children and adults. A review of 110 cases. Am J Med (1977) 62(2):200-8. doi:10.1016/0002-9343(77)90315-1

14. Steinherz LJ, Steinherz PG, Tan CT, Heller G, Murphy ML. Cardiac toxicity 4 to 20 years after completing anthracycline therapy. JAMA (1991) 266(12):1672-7. doi:10.1001/jama.266.12.1672

15. Lipshultz SE, Colan SD, Gelber RD, Perez-Atayde AR, Sallan SE, Sanders SP. Late cardiac effects of doxorubicin therapy for acute lymphoblastic leukemia in childhood. N Engl J Med (1991) 324(12):808-15. doi:10.1056/ NEJM199103213241205

16. Goldberg JM, Scully RE, Sallan SE, Lipshultz SE. Cardiac failure 30 years after treatment containing anthracycline for childhood acute lymphoblastic leukemia. J Pediatr Hematol Oncol (2012) 34(5):395-7. doi:10.1097/MPH. 0b013e3182532078

17. Mertens AC, Liu Q, Neglia JP, Wasilewski K, Leisenring W, Armstrong GT, et al. Cause-specific late mortality among 5-year survivors of childhood cancer: the Childhood Cancer Survivor Study. J Natl Cancer Inst (2008) 100(19):1368-79. doi:10.1093/jnci/djn310

18. Oeffinger KC, Mertens AC, Sklar CA, Kawashima T, Hudson MM, Meadows AT, et al. Chronic health conditions in adult survivors of childhood cancer. $N$ Engl J Med (2006) 355(15):1572-82. doi:10.1056/NEJMsa060185

19. Slamon DJ, Clark GM, Wong SG, Levin WJ, Ullrich A, McGuire WL. Human breast cancer: correlation of relapse and survival with amplification of the 
HER-2/neu oncogene. Science (1987) 235(4785):177-82. doi:10.1126/science. 3798106

20. Costa RB, Kurra G, Greenberg L, Geyer CE. Efficacy and cardiac safety of adjuvant trastuzumab-based chemotherapy regimens for HER2-positive early breast cancer. Ann Oncol (2010) 21(11):2153-60. doi:10.1093/annonc/mdq096

21. Chien AJ, Rugo HS. The cardiac safety of trastuzumab in the treatment of breast cancer. Expert Opin Drug Saf (2010) 9(2):335-46. doi:10.1517/ 14740331003627441

22. Tripathy D, Slamon DJ, Cobleigh M, Arnold A, Saleh M, Mortimer JE, et al. Safety of treatment of metastatic breast cancer with trastuzumab beyond disease progression. J Clin Oncol (2004) 22(6):1063-70. doi:10.1200/JCO.2004. 06.557

23. Ewer MS, Vooletich MT, Durand JB, Woods ML, Davis JR, Valero V, et al. Reversibility of trastuzumab-related cardiotoxicity: new insights based on clinical course and response to medical treatment. J Clin Oncol (2005) 23(31):7820-6. doi:10.1200/JCO.2005.13.300

24. Suter TM, Procter M, van Veldhuisen DJ, Muscholl M, Bergh J, Carlomagno C, et al. Trastuzumab-associated cardiac adverse effects in the herceptin adjuvant trial. J Clin Oncol (2007) 25(25):3859-65. doi:10.1200/JCO.2006.09.1611

25. Seidman A, Hudis C, Pierri MK, Shak S, Paton V, Ashby M, et al. Cardiac dysfunction in the trastuzumab clinical trials experience. J Clin Oncol (2002) 20(5):1215-21. doi:10.1200/JCO.20.5.1215

26. Baselga J, Bradbury I, Eidtmann H, Di Cosimo S, de Azambuja E, Aura C, et al. Lapatinib with trastuzumab for HER2-positive early breast cancer (NeoALTTO): a randomised, open-label, multicentre, phase 3 trial. Lancet (2012) 379(9816):633-40. doi:10.1016/S0140-6736(11)61847-3

27. Baselga J, Cortes J, Kim SB, Im SA, Hegg R, Im YH, et al. Pertuzumab plus trastuzumab plus docetaxel for metastatic breast cancer. N Engl J Med (2012) 366(2):109-19. doi:10.1056/NEJMoa1113216

28. Blackwell KL, Burstein HJ, Storniolo AM, Rugo HS, Sledge G, Aktan G, et al. Overall survival benefit with lapatinib in combination with trastuzumab for patients with human epidermal growth factor receptor 2-positive metastatic breast cancer: final results from the EGF104900 Study. J Clin Oncol (2012) 30(21):2585-92. doi:10.1200/JCO.2011.35.6725

29. Burris HA III, Rugo HS, Vukelja SJ, Vogel CL, Borson RA, Limentani S, et al. Phase II study of the antibody drug conjugate trastuzumab-DM1 for the treatment of human epidermal growth factor receptor 2 (HER2)-positive breast cancer after prior HER2-directed therapy. J Clin Oncol (2011) 29(4):398-405. doi:10.1200/JCO.2010.29.5865

30. Burstein HJ, Sun Y, Dirix LY, Jiang Z, Paridaens R, Tan AR, et al. Neratinib, an irreversible ErbB receptor tyrosine kinase inhibitor, in patients with advanced ErbB2-positive breast cancer. J Clin Oncol (2010) 28(8):1301-7. doi:10.1200/JCO.2009.25.8707

31. Gianni L, Pienkowski T, Im YH, Roman L, Tseng LM, Liu MC, et al. Efficacy and safety of neoadjuvant pertuzumab and trastuzumab in women with locally advanced, inflammatory, or early HER2-positive breast cancer (NeoSphere): a randomised multicentre, open-label, phase 2 trial. Lancet Oncol (2012) 13(1):25-32. doi:10.1016/S1470-2045(11)70336-9

32. Hurvitz SA, Dirix L, Kocsis J, Bianchi GV, Lu J, Vinholes J, et al. Phase II randomized study of trastuzumab emtansine versus trastuzumab plus docetaxel in patients with human epidermal growth factor receptor 2-positive metastatic breast cancer. J Clin Oncol (2013) 31(9):1157-63. doi:10.1200/JCO.2012.44. 9694

33. Krop IE, LoRusso P, Miller KD, Modi S, Yardley D, Rodriguez G, et al. A phase II study of trastuzumab emtansine in patients with human epidermal growth factor receptor 2-positive metastatic breast cancer who were previously treated with trastuzumab, lapatinib, an anthracycline, a taxane, and capecitabine. JClin Oncol (2012) 30(26):3234-41. doi:10.1200/JCO.2011.40.5902

34. Robidoux A, Tang G, Rastogi P, Geyer CE Jr, Azar CA, Atkins JN, et al. Lapatinib as a component of neoadjuvant therapy for HER2-positive operable breast cancer (NSABP protocol B-41): an open-label, randomised phase 3 trial. Lancet Oncol (2013) 14(12):1183-92. doi:10.1016/S1470-2045(13)70411-X

35. Clarke M, Collins R, Darby S, Davies C, Elphinstone P, Evans E, et al. Effects of radiotherapy and of differences in the extent of surgery for early breast cancer on local recurrence and 15-year survival: an overview of the randomised trials. Lancet (2005) 366(9503):2087-106. doi:10.1016/S0140-6736(05)67887-7
36. Cuzick J, Stewart H, Rutqvist L, Houghton J, Edwards R, Redmond C, et al. Cause-specific mortality in long-term survivors of breast cancer who participated in trials of radiotherapy. J Clin Oncol (1994) 12(3):447-53.

37. Senkus-Konefka E, Jassem J. Cardiovascular effects of breast cancer radiotherapy. Cancer Treat Rev (2007) 33(6):578-93. doi:10.1016/j.ctrv.2007.07.011

38. Darby SC, McGale P, Taylor CW, Peto R. Long-term mortality from heart disease and lung cancer after radiotherapy for early breast cancer: prospective cohort study of about 300,000 women in US SEER cancer registries. Lancet Oncol (2005) 6(8):557-65. doi:10.1016/S1470-2045(05)70251-5

39. Gagliardi G, Constine LS, Moiseenko V, Correa C, Pierce LJ, Allen AM, et al. Radiation dose-volume effects in the heart. Int J Radiat Oncol Biol Phys (2010) 76(3 Suppl):S77-85. doi:10.1016/j.ijrobp.2009.04.093

40. Shapiro CL, Hardenbergh PH, Gelman R, Blanks D, Hauptman P, Recht A, et al. Cardiac effects of adjuvant doxorubicin and radiation therapy in breast cancer patients. J Clin Oncol (1998) 16(11):3493-501.

41. Von Hoff DD, Layard MW, Basa P, Davis HL Jr, Von Hoff AL, Rozencweig M, et al. Risk factors for doxorubicin-induced congestive heart failure. Ann Intern Med (1979) 91(5):710-7. doi:10.7326/0003-4819-91-5-710

42. Halyard MY, Pisansky TM, Dueck AC, Suman V, Pierce L, Solin L, et al. Radiotherapy and adjuvant trastuzumab in operable breast cancer: tolerability and adverse event data from the NCCTG Phase III Trial N9831. J Clin Oncol (2009) 27(16):2638-44. doi:10.1200/JCO.2008.17.9549

43. Giordano SH, Kuo YF, Freeman JL, Buchholz TA, Hortobagyi GN, Goodwin JS. Risk of cardiac death after adjuvant radiotherapy for breast cancer. J Natl Cancer Inst (2005) 97(6):419-24. doi:10.1093/jnci/dji067

44. Patt DA, Goodwin JS, Kuo YF, Freeman JL, Zhang DD, Buchholz TA, et al. Cardiac morbidity of adjuvant radiotherapy for breast cancer. J Clin Oncol (2005) 23(30):7475-82. doi:10.1200/JCO.2005.13.755

45. Cooper LT, Baughman KL, Feldman AM, Frustaci A, Jessup M, Kuhl U, et al. The role of endomyocardial biopsy in the management of cardiovascular disease: a scientific statement from the American Heart Association, the American College of Cardiology, and the European Society of Cardiology. J Am Coll Cardiol (2007) 50(19):1914-31. doi:10.1016/j.jacc.2007.09.008

46. Altena R, Perik PJ, van Veldhuisen DJ, de Vries EG, Gietema JA. Cardiovascular toxicity caused by cancer treatment: strategies for early detection. Lancet Oncol (2009) 10(4):391-9. doi:10.1016/S1470-2045(09)70042-7

47. Mitani I, Jain D, Joska TM, Burtness B, Zaret BL. Doxorubicin cardiotoxicity: prevention of congestive heart failure with serial cardiac function monitoring with equilibrium radionuclide angiocardiography in the current era. $\mathrm{J} \mathrm{Nucl}$ Cardiol (2003) 10(2):132-9. doi:10.1067/mnc.2003.7

48. Walker J, Bhullar N, Fallah-Rad N, Lytwyn M, Golian M, Fang T, et al. Role of three-dimensional echocardiography in breast cancer: comparison with two-dimensional echocardiography, multiple-gated acquisition scans, and cardiac magnetic resonance imaging. J Clin Oncol (2010) 28(21):3429-36. doi:10.1200/JCO.2009.26.7294

49. Ganame J, Claus P, Uyttebroeck A, Renard M, D’Hooge J, Bijnens B, et al. Myocardial dysfunction late after low-dose anthracycline treatment in asymptomatic pediatric patients. J Am Soc Echocardiogr (2007) 20(12):1351-8. doi:10.1016/j.echo.2007.04.007

50. Armstrong GT, Plana JC, Zhang N, Srivastava D, Green DM, Ness KK, et al. Screening adult survivors of childhood cancer for cardiomyopathy: comparison of echocardiography and cardiac magnetic resonance imaging. J Clin Oncol (2012) 30(23):2876-84. doi:10.1200/JCO.2011.40.3584

51. Fallah-Rad N, Walker JR, Wassef A, Lytwyn M, Bohonis S, Fang T, et al. The utility of cardiac biomarkers, tissue velocity and strain imaging, and cardiac magnetic resonance imaging in predicting early left ventricular dysfunction in patients with human epidermal growth factor receptor II-positive breast cancer treated with adjuvant trastuzumab therapy. J Am Coll Cardiol (2011) 57(22):2263-70. doi:10.1016/j.jacc.2010.11.063

52. Swain SM, Whaley FS, Ewer MS. Congestive heart failure in patients treated with doxorubicin: a retrospective analysis of three trials. Cancer (2003) 97(11):2869-79. doi:10.1002/cncr.11407

53. Jensen BV, Skovsgaard T, Nielsen SL. Functional monitoring of anthracycline cardiotoxicity: a prospective, blinded, long-term observational study of outcome in 120 patients. Ann Oncol (2002) 13(5):699-709. doi:10.1093/annonc/ mdf132 
54. Babuin L, Jaffe AS. Troponin: the biomarker of choice for the detection of cardiac injury. Can Med Associat J (2005) 173(10):1191-202. doi:10.1503/cmaj/ 051291

55. O'Brien PJ. Cardiac troponin is the most effective translational safety biomarker for myocardial injury in cardiotoxicity. Toxicology (2008) 245(3):206-18. doi:10.1016/j.tox.2007.12.006

56. Adamcova M, Sterba M, Simunek T, Potacova A, Popelova O, Mazurova Y, et al. Troponin as a marker of myocardiac damage in drug-induced cardiotoxicity. Expert Opin Drug Saf (2005) 4(3):457-72. doi:10.1517/14740338.4.3.457

57. Jensen JK, Atar D, Mickley H. Mechanism of troponin elevations in patients with acute ischemic stroke. Am J Cardiol (2007) 99(6):867-70. doi:10.1016/j. amjcard.2006.07.071

58. Panteghini M. Role and importance of biochemical markers in clinical cardiology. Eur Heart J (2004) 25(14):1187-96. doi:10.1016/j.ehj.2004.04.026

59. Herman EH, Zhang J, Lipshultz SE, Rifai N, Chadwick D, Takeda K, et al. Correlation between serum levels of cardiac troponin- $\mathrm{T}$ and the severity of the chronic cardiomyopathy induced by doxorubicin. J Clin Oncol (1999) 17(7):2237-43.

60. Cardinale D, Sandri MT, Martinoni A, Tricca A, Civelli M, Lamantia G, et al. Left ventricular dysfunction predicted by early troponin I release after high-dose chemotherapy. J Am Coll Cardiol (2000) 36(2):517-22. doi:10.1016/S07351097(00)00748-8

61. Cardinale D. Myocardial injury revealed by plasma troponin I in breast cancer treated with high-dose chemotherapy. Ann Oncol (2002) 13(5):710-5. doi:10.1093/annonc/mdf170

62. Cardinale D, Sandri MT, Colombo A, Colombo N, Boeri M, Lamantia G, et al. Prognostic value of troponin I in cardiac risk stratification of cancer patients undergoing high-dose chemotherapy. Circulation (2004) 109(22):2749-54. doi:10.1161/01.CIR.0000130926.51766.CC

63. Sandri MT, Cardinale D, Zorzino L, Passerini R, Lentati P, Martinoni A, et al. Minor increases in plasma troponin I predict decreased left ventricular ejection fraction after high-dose chemotherapy. Clin Chem (2003) 49(2):248-52. doi:10.1373/49.2.248

64. Hughes-Davies L, Sacks D, Rescigno J, Howard S, Harris J. Serum cardiac troponin T levels during treatment of early-stage breast cancer. J Clin Oncol (1995) 13(10):2582-4

65. Lipshultz SE, Rifai N, Sallan SE, Lipsitz SR, Dalton V, Sacks DB, et al. Predictive value of cardiac troponin $\mathrm{T}$ in pediatric patients at risk for myocardial injury. Circulation (1997) 96(8):2641-8. doi:10.1161/01.CIR.96.8.2641

66. Auner HW, Tinchon C, Linkesch W, Tiran A, Quehenberger F, Link H, et al. Prolonged monitoring of troponin $\mathrm{T}$ for the detection of anthracycline cardiotoxicity in adults with hematological malignancies. Ann Hematol (2003) 82(4):218-22. doi:10.1007/s00277-003-0615-3

67. Kismet E, Varan A, Ayabakan C, Alehan D, Portakal O, Buyukpamukcu M. Serum troponin $\mathrm{T}$ levels and echocardiographic evaluation in children treated with doxorubicin. Pediatr Blood Cancer (2004) 42(3):220-4. doi:10.1002/pbc. 10368

68. Lipshultz SE, Rifai N, Dalton VM, Levy DE, Silverman LB, Lipsitz SR, et al. The effect of dexrazoxane on myocardial injury in doxorubicin-treated children with acute lymphoblastic leukemia. N Engl J Med (2004) 351(2):145-53. doi:10.1056/NEJMoa035153

69. Kilickap S, Barista I, Akgul E, Aytemir K, Aksoyek S, Aksoy S, et al. cTnT can be a useful marker for early detection of anthracycline cardiotoxicity. Ann Oncol (2005) 16(5):798-804. doi:10.1093/annonc/mdi152

70. Perik PJ, Lub-De Hooge MN, Gietema JA, van der Graaf WT, de Korte MA, Jonkman S, et al. Indium-111-labeled trastuzumab scintigraphy in patients with human epidermal growth factor receptor 2-positive metastatic breast cancer. J Clin Oncol (2006) 24(15):2276-82. doi:10.1200/JCO.2005.03.8448

71. Dodos F, Halbsguth T, Erdmann E, Hoppe UC. Usefulness of myocardial performance index and biochemical markers for early detection of anthracyclineinduced cardiotoxicity in adults. Clin Res Cardiol (2008) 97(5):318-26. doi:10.1007/s00392-007-0633-6

72. Kozak KR, Hong TS, Sluss PM, Lewandrowski EL, Aleryani SL, Macdonald SM, et al. Cardiac blood biomarkers in patients receiving thoracic (chemo)radiation. Lung Cancer (2008) 62(3):351-5. doi:10.1016/j.lungcan. 2008.03.024

73. Cil T, Kaplan AM, Altintas A, Akin AM, Alan S, Isikdogan A. Use of N-terminal pro-brain natriuretic peptide to assess left ventricular function after adjuvant doxorubicin therapy in early breast cancer patients: a prospective series. Clin Drug Investig (2009) 29(2):131-7. doi:10.2165/0044011-200929020-00007

74. Mavinkurve-Groothuis AM, Groot-Loonen J, Bellersen L, Pourier MS, Feuth T, Bökkerink JP, et al. Abnormal NT-pro-BNP levels in asymptomatic long-term survivors of childhood cancer treated with anthracyclines. Pediatr Blood Cancer (2009) 52(5):631-6. doi:10.1002/pbc.21913

75. Cardinale D, Colombo A, Torrisi R, Sandri MT, Civelli M, Salvatici M, et al. Trastuzumab-induced cardiotoxicity: clinical and prognostic implications of troponin I evaluation. J Clin Oncol (2010) 28(25):3910-6. doi:10.1200/JCO. 2009.27.3615

76. Nellessen U, Zingel M, Hecker H, Bahnsen J, Borschke D. Effects of radiation therapy on myocardial cell integrity and pump function: which role for cardiac biomarkers? Chemotherapy (2010) 56(2):147-52. doi:10.1159/000313528

77. Feola M, Garrone O, Occelli M, Francini A, Biggi A, Visconti G, et al. Cardiotoxicity after anthracycline chemotherapy in breast carcinoma: effects on left ventricular ejection fraction, troponin I and brain natriuretic peptide. Int J Cardiol (2011) 148(2):194-8. doi:10.1016/j.ijcard.2009.09.564

78. Goel S, Simes RJ, Beith JM. Exploratory analysis of cardiac biomarkers in women with normal cardiac function receiving trastuzumab for breast cancer. Asia Pac J Clin Oncol (2011) 7(3):276-80. doi:10.1111/j.1743-7563.2011. 01422.x

79. Morris PG, Chen C, Steingart R, Fleisher M, Lin N, Moy B, et al. Troponin I and $\mathrm{C}$-reactive protein are commonly detected in patients with breast cancer treated with dose-dense chemotherapy incorporating trastuzumab and lapatinib. Clin Cancer Res (2011) 17(10):3490-9. doi:10.1158/1078-0432.CCR-10-1359

80. Romano S, Fratini S, Ricevuto E, Procaccini V, Stifano G, Mancini M, et al. Serial measurements of NT-proBNP are predictive of not-high-dose anthracycline cardiotoxicity in breast cancer patients. Br J Cancer (2011) 105(11):1663-8. doi:10.1038/bjc.2011.439

81. Sawaya H, Sebag IA, Plana JC, Januzzi JL, Ky B, Cohen V, et al. Early detection and prediction of cardiotoxicity in chemotherapy-treated patients. Am J Cardiol (2011) 107(9):1375-80. doi:10.1016/j.amjcard.2011.01.006

82. D’Errico MP, Grimaldi L, Petruzzelli MF, Gianicolo EA, Tramacere F, Monetti A, et al. N-terminal pro-B-type natriuretic peptide plasma levels as a potential biomarker for cardiac damage after radiotherapy in patients with left-sided breast cancer. Int J Radiat Oncol Biol Phys (2012) 82(2):e239-46. doi:10.1016/j.ijrobp.2011.03.058

83. Garrone O, Crosetto N, Lo Nigro C, Catzeddu T, Vivenza D, Monteverde M, et al. Prediction of anthracycline cardiotoxicity after chemotherapy by biomarkers kinetic analysis. Cardiovasc Toxicol (2012) 12(2):135-42. doi:10.1007/ s12012-011-9149-4

84. Lipshultz SE, Miller TL, Scully RE, Lipsitz SR, Rifai N, Silverman LB, et al. Changes in cardiac biomarkers during doxorubicin treatment of pediatric patients with high-risk acute lymphoblastic leukemia: associations with long-term echocardiographic outcomes. J Clin Oncol (2012) 30(10):1042-9. doi:10.1200/JCO.2010.30.3404

85. Onitilo AA, Engel JM, Stankowski RV, Liang H, Berg RL, Doi SA. Highsensitivity C-reactive protein (hs-CRP) as a biomarker for trastuzumabinduced cardiotoxicity in HER2-positive early-stage breast cancer: a pilot study. Breast Cancer Res Treat (2012) 134(1):291-8. doi:10.1007/s10549-012-2039-z

86. Sawaya H, Sebag IA, Plana JC, Januzzi JL, Ky B, Tan TC, et al. Assessment of echocardiography and biomarkers for the extended prediction of cardiotoxicity in patients treated with anthracyclines, taxanes, and trastuzumab. Circul Cardiovasc Imag (2012) 5(5):596-603. doi:10.1161/CIRCIMAGING.112.973321

87. Sherief LM, Kamal AG, Khalek EA, Kamal NM, Soliman AA, Esh AM. Biomarkers and early detection of late onset anthracycline-induced cardiotoxicity in children. Hematology (2012) 17(3):151-6. doi:10.1179/ 102453312 X13376952196412

88. Erven K, Florian A, Slagmolen P, Sweldens C, Jurcut R, Wildiers H, et al. Subclinical cardiotoxicity detected by strain rate imaging up to 14 months after breast radiation therapy. Int J Radiat Oncol Biol Phys (2013) 85(5):1172-8. doi:10.1016/j.ijrobp.2012.09.022

89. Ky B, Putt M, Sawaya H, French B, Januzzi JL Jr, Sebag IA, et al. Early increases in multiple biomarkers predict subsequent cardiotoxicity in patients with breast cancer treated with doxorubicin, taxanes, and trastuzumab. J Am Coll Cardiol (2014) 63(8):809-16. doi:10.1016/j.jacc.2013.10.061

90. Pongprot Y, Sittiwangkul R, Charoenkwan P, Silvilairat S. Use of cardiac markers for monitoring of doxorubixin-induced cardiotoxicity in children 
with cancer. J Pediatr Hematol Oncol (2012) 34(8):589-95. doi:10.1097/MPH. 0b013e31826faf44

91. Jensen KT, Carstens J, Pedersen EB. Effect of BNP on renal hemodynamics, tubular function and vasoactive hormones in humans. Am J Physiol (1998) 274(1 Pt 2):F63-72.

92. Grewal J, McKelvie RS, Persson H, Tait P, Carlsson J, Swedberg K, et al. Usefulness of $\mathrm{N}$-terminal pro-brain natriuretic Peptide and brain natriuretic peptide to predict cardiovascular outcomes in patients with heart failure and preserved left ventricular ejection fraction. Am J Cardiol (2008) 102(6):733-7. doi:10.1016/j.amjcard.2008.04.048

93. Masson S, Latini R. Amino-terminal pro-B-type natriuretic peptides and prognosis in chronic heart failure. Am J Cardiol (2008) 101(3A):56-60. doi:10.1016/j.amjcard.2007.11.024

94. Yu CM, Sanderson JE, Shum IO, Chan S, Yeung LY, Hung YT, et al. Diastolic dysfunction and natriuretic peptides in systolic heart failure. Higher ANP and BNP levels are associated with the restrictive filling pattern. Eur Heart J (1996) 17(11):1694-702. doi:10.1093/oxfordjournals.eurheartj.a014753

95. Selvais PL, Donckier JE, Robert A, Laloux O, van Linden F, Ahn S, et al. Cardiac natriuretic peptides for diagnosis and risk stratification in heart failure: influences of left ventricular dysfunction and coronary artery disease on cardiac hormonal activation. Eur J Clin Invest (1998) 28(8):636-42. doi:10.1046/j.1365-2362.1998.00338.x

96. ElGhandour AH, El Sorady M, Azab S, ElRahman M. Human heart-type fatty acid-binding protein as an early diagnostic marker of doxorubicin cardiac toxicity. Hematol Rep (2009) 1:1. doi:10.4081/hr.2009.e6

97. Kouloubinis A, Kaklamanis L, Ziras N, Sofroniadou S, Makaritsis K, Adamopoulos S, et al. ProANP and NT-proBNP levels to prospectively assess cardiac function in breast cancer patients treated with cardiotoxic chemotherapy. Int J Cardiol (2007) 122(3):195-201. doi:10.1016/j.ijcard.2006.11.076

98. Meinardi MT, van Veldhuisen DJ, Gietema JA, Dolsma WV, Boomsma F, van denBerg MP, et al. Prospective evaluation of early cardiac damage induced by epirubicin-containing adjuvant chemotherapy and locoregional radiotherapy in breast cancer patients. J Clin Oncol (2001) 19(10):2746-53.

99. Nousiainen T, Vanninen E, Jantunen E, Puustinen J, Remes J, Rantala A, et al. Natriuretic peptides during the development of doxorubicin-induced left ventricular diastolic dysfunction. J Intern Med (2002) 251(3):228-34. doi:10.1046/j.1365-2796.2002.00951.x

100. Daugaard G, Lassen U, Bie P, Pedersen EB, Jensen KT, Abildgaard U, et al. Natriuretic peptides in the monitoring of anthracycline induced reduction in left ventricular ejection fraction. Eur J Heart Failure (2005) 7(1):87-93. doi:10.1016/j.ejheart.2004.03.009

101. Perik PJ, De Vries EG, Boomsma F, van der Graaf WT, Sleijfer DT, van Veldhuisen DJ, et al. Use of natriuretic peptides for detecting cardiac dysfunction in long-term disease-free breast cancer survivors. Anticancer Res (2005) 25(5):3651-7.

102. Sandri MT, Salvatici M, Cardinale D, Zorzino L, Passerini R, Lentati P, et al. $\mathrm{N}$-terminal pro-B-type natriuretic peptide after high-dose chemotherapy: a marker predictive of cardiac dysfunction? Clin Chem (2005) 51(8):1405-10. doi:10.1373/clinchem.2005.050153

103. Germanakis I, Kalmanti M, Parthenakis F, Nikitovic D, Stiakaki E, Patrianakos A, et al. Correlation of plasma N-terminal pro-brain natriuretic peptide levels with left ventricle mass in children treated with anthracyclines. Int J Cardiol (2006) 108(2):212-5. doi:10.1016/j.ijcard.2005.05.006

104. Aggarwal S, Pettersen MD, Bhambhani K, Gurczynski J, Thomas R, L’Ecuyer T. B-type natriuretic peptide as a marker for cardiac dysfunction in anthracyclinetreated children. Pediatr Blood Cancer (2007) 49(6):812-6. doi:10.1002/pbc. 21100

105. Ekstein S, Nir A, Rein AJ, Perles Z, Bar-Oz B, Salpeter L, et al. N-terminalproB-type natriuretic peptide as a marker for acute anthracycline cardiotoxicity in children. J Pediatr Hematol Oncol (2007) 29(7):440-4. doi:10.1097/MPH. 0b013e3180640d42

106. Jingu K, Nemoto K, Kaneta T, Oikawa M, Ogawa Y, Ariga H, et al. Temporal change in brain natriuretic Peptide after radiotherapy for thoracic esophageal cancer. Int J Radiat Oncol Biol Phys (2007) 69(5):1417-23. doi:10.1016/j.ijrobp. 2007.05.054

107. Albers S, Mir TS, Haddad M, Laer SN. Terminal pro-brain natriuretic peptide: normal ranges in the pediatric population including method comparison and interlaboratory variability. Clin Chem Lab Med (2006) 44(1):80-5. doi:10. 1515/CCLM.2006.016

108. Mladosievicova B, Urbanova D, Radvanska E, Slavkovsky P, Simkova I. Role of NT-proBNP in detection of myocardial damage in childhood leukemia survivors treated with and without anthracyclines. J Exp Clin Cancer Res (2012) 31:86. doi:10.1186/1756-9966-31-86

109. Nir A, Lindinger A, Rauh M, Bar-Oz B, Laer S, Schwachtgen L, et al. NTpro-B-type natriuretic peptide in infants and children: reference values based on combined data from four studies. Pediatr Cardiol (2009) 30(1):3-8. doi:10.1007/s00246-008-9258-4

110. Kittiwarawut A, Vorasettakarnkij Y, Tanasanvimon S, Manasnayakorn S, Sriuranpong V. Serum NT-proBNP in the early detection of doxorubicin-induced cardiac dysfunction. Asia Pac J Clin Oncol (2013) 9(2):155-61. doi:10.1111/j. 1743-7563.2012.01588.x

111. O’Donoghue M, de Lemos JA, Morrow DA, Murphy SA, Buros JL, Cannon CP, et al. Prognostic utility of heart-type fatty acid binding protein in patients with acute coronary syndromes. Circulation (2006) 114(6):550-7. doi:10.1161/CIRCULATIONAHA.106.641936

112. Glatz JF, van der Vusse GJ, Simoons ML, Kragten JA, van Dieijen-Visser MP, Hermens WT. Fatty acid-binding protein and the early detection of acute myocardial infarction. Clin Chim Acta (1998) 272(1):87-92. doi:10.1016/ S0009-8981(97)00255-6

113. Azzazy HM, Pelsers MM, Christenson RH. Unbound free fatty acids and hearttype fatty acid-binding protein: diagnostic assays and clinical applications. Clin Chem (2006) 52(1):19-29. doi:10.1373/clinchem.2005.056143

114. Horacek JM, Jebavy L, Ulrychova M, Tichy M, Pudil R, Zak P, et al. Glycogen phosphorylase BB could be a new biomarker for detection of cardiac toxicity during hematopoietic cell transplantation for hematological malignancies. Bone Marrow Transplant (2010) 45(6):1123-4. doi:10.1038/bmt.2009.306

115. Horacek JM, Tichy M, Pudil R, Jebavy L. Glycogen phosphorylase BB could be a new circulating biomarker for detection of anthracycline cardiotoxicity. Ann Oncol (2008) 19(9):1656-7. doi:10.1093/annonc/mdn414

116. Horacek JM, Vasatova M, Tichy M, Pudil R, Jebavy L, Maly J. The use of cardiac biomarkers in detection of cardiotoxicity associated with conventional and high-dose chemotherapy for acute leukemia. Exp Oncol (2010) 32(2):97-9.

117. Arruda-Olson AM, Enriquez-Sarano M, Bursi F, Weston SA, Jaffe AS, Killian JM, et al. Left ventricular function and C-reactive protein levels in acute myocardial infarction. Am J Cardiol (2010) 105(7):917-21. doi:10.1016/j. amjcard.2009.11.025

118. Arroyo-Espliguero R, Avanzas P, Quiles J, Kaski JC. Predictive value of coronary artery stenoses and C-reactive protein levels in patients with stable coronary artery disease. Atherosclerosis (2009) 204(1):239-43. doi:10.1016/j. atherosclerosis.2008.08.009

119. Windram JD, Loh PH, Rigby AS, Hanning I, Clark AL, Cleland JG. Relationship of high-sensitivity C-reactive protein to prognosis and other prognostic markers in outpatients with heart failure. Am Heart J (2007) 153(6):1048-55. doi:10.1016/j.ahj.2007.03.044

120. Lipshultz SE, Landy DC, Lopez-Mitnik G, Lipsitz SR, Hinkle AS, Constine LS, et al. Cardiovascular status of childhood cancer survivors exposed and unexposed to cardiotoxic therapy. J Clin Oncol (2012) 30(10):1050-7. doi:10.1200/JCO.2010.33.7907

121. Baldus S, Heeschen C, Meinertz T, Zeiher AM, Eiserich JP, Münzel T, et al. Myeloperoxidase serum levels predict risk in patients with acute coronary syndromes. Circulation (2003) 108(12):1440-5. doi:10.1161/01.CIR.0000090690. 67322.51

122. Tang WH, Tong W, Troughton RW, Martin MG, Shrestha K, Borowski A, et al. Prognostic value and echocardiographic determinants of plasma myeloperoxidase levels in chronic heart failure. J Am Coll Cardiol (2007) 49(24):2364-70. doi:10.1016/j.jacc.2007.02.053

123. Moncada S, Palmer RM, Higgs EA. Nitric oxide: physiology, pathophysiology, and pharmacology. Pharmacol Rev (1991) 43(2):109-42.

124. Haywood GA, Tsao PS, von derLeyen HE, Mann MJ, Keeling PJ, Trindade PT, et al. Expression of inducible nitric oxide synthase in human heart failure. Circulation (1996) 93(6):1087-94. doi:10.1161/01.CIR.93.6.1087

125. Winlaw DS, Smythe GA, Keogh AM, Schyvens CG, Spratt PM, Macdonald PS. Increased nitric oxide production in heart failure. Lancet (1994) 344(8919):373-4. doi:10.1016/S0140-6736(94)91403-6 
126. Kalivendi SV, Kotamraju S, Zhao H, Joseph J, Kalyanaraman B. Doxorubicininduced apoptosis is associated with increased transcription of endothelial nitric-oxide synthase. Effect of antiapoptotic antioxidants and calcium. J Biol Chem (2001) 276(50):47266-76. doi:10.1074/jbc.M106829200

127. Pacher P, Liaudet L, Bai P, Mabley JG, Kaminski PM, Virág L, et al. Potent metalloporphyrin peroxynitrite decomposition catalyst protects against the development of doxorubicin-induced cardiac dysfunction. Circulation (2003) 107(6):896-904. doi:10.1161/01.CIR.0000048192.52098.DD

128. Guler E, Baspinar O, Cekmen M, Kilinc M, Balat A. Nitric oxide: a new biomarker of Doxorubicin toxicity in children? Pediatr Hematol Oncol (2011) 28(5):395-402. doi:10.3109/08880018.2011.563373

129. Wilson JM, Jungner YG. Principles and practice of mass screening for disease. Bol Oficina Sanit Panam (1968) 65(4):281-93.

130. Cardinale D, Colombo A, Sandri MT, Lamantia G, Colombo N, Civelli M, et al. Prevention of high-dose chemotherapy-induced cardiotoxicity in high-risk patients by angiotensin-converting enzyme inhibition. Circulation (2006) 114(23):2474-81. doi:10.1161/CIRCULATIONAHA.106. 635144

131. Kaya MG, Ozkan M, Gunebakmaz O, Akkaya H, Kaya EG, Akpek M, et al. Protective effects of nebivolol against anthracycline-induced cardiomyopathy: a randomized control study. Int J Cardiol (2013) 167(5):2306-10. doi:10.1016/j. ijcard.2012.06.023
132. Kalay N, Basar E, Ozdogru I, Er O, Cetinkaya Y, Dogan A, et al. Protective effects of carvedilol against anthracycline-induced cardiomyopathy. J Am Coll Cardiol (2006) 48(11):2258-62. doi:10.1016/j.jacc.2006.07.052

Conflict of Interest Statement: The authors declare that the research was conducted in the absence of any commercial or financial relationships that could be construed as a potential conflict of interest.

Received: 30 July 2014; accepted: 23 September 2014; published online: 09 October 2014.

Citation: Tian S, Hirshfield KM, Jabbour SK, Toppmeyer D, Haffty BG, Khan AJ and Goyal S (2014) Serum biomarkers for the detection of cardiac toxicity after chemotherapy and radiation therapy in breast cancer patients. Front. Oncol. 4:277. doi: 10.3389/fonc.2014.00277

This article was submitted to Radiation Oncology, a section of the journal Frontiers in Oncology.

Copyright (C) 2014 Tian, Hirshfield, Jabbour, Toppmeyer, Haffty, Khan and Goyal. This is an open-access article distributed under the terms of the Creative Commons Attribution License (CC BY). The use, distribution or reproduction in other forums is permitted, provided the original author(s) or licensor are credited and that the original publication in this journal is cited, in accordance with accepted academic practice. No use, distribution or reproduction is permitted which does not comply with these terms. 